\title{
INTERTEXTOS PARATEATRALES EN EL CINE DE PEDRO ALMODÓVAR
}

\author{
Paratheatrical Intertexts in the Cinema by Pedro Almodóvar
}

\author{
MARIO DE LA TORRE-ESPINOSA \\ UNIVERSIDAD DE GRANADA (ESPAÑA) \\ mariodelatorre@ugr.es http://orcid.org/0000-0002-0027-8745
}

\section{RECIBIDO: 5 DE OCTUBRE DE 2018 ACEPTADO: 25 DE FEBRERO DE 2019}

RESUMEN: La filmografía de Pedro Almodóvar ha sido considerada como paradigma de la teatralidad en el cine, como lo demuestra la gran cantidad de bibliografía que defiende este punto de vista. Esto se debe, entre otras cuestiones, a la presencia de intertextos teatrales, pero también a otros parateatrales, entendidos estos como ciertas formas espectaculares que asumen algunos principios de la práctica escénica, como la existencia de al menos un actor y un espectador. En este artículo se identifican intertextos parateatrales pertenecientes al mundo de la tauromaquia, la liturgia católica, las artes plásticas usadas como escenografía, lo metacinematográfico y el mundo de la moda. Se observa cómo en la totalidad de las obras de Almodóvar existen intertextos de esta naturaleza, contribuyendo notablemente a la constitución de la visión theatrum mundi que subyace en toda su producción cinematográfica, asociándose a una estética posmoderna en cuanto lo artificioso prima sobre otras cuestiones.

Palabras Clave: Parateatralidad, Intermedialidad, Pedro Almodóvar, Tauromaquia, Liturgia católica, Cine español.

ABSTRACT: The filmography of Pedro Almodóvar has been considered as a paradigm of theatricality in cinema. Indeed, a huge amount of bibliography has been generated from this point of view. This is because, among other reasons, the presence of theatrical intertexts, but also the paratheatrical ones, understood as certain performative forms that assume some principles of the stage representation such as the existence of at least one actor and one spectator. In this article are identified different paratheatrical intertexts belonging to the bullfighting scene, the catholic liturgy, the plastic arts used as scenography, the metacinematographic elements and the fashion world. Can be seen how throughout the Almodovar's films there is a strong presence of paratheatrical intertexts, significantly contributing to the theatrum mundi vision of his cinema, linked to a postmodern aesthetic because, among other issues, the importance of the artifice nature of his movies.

KEYwORDs: Paratheatricality, Intermediality, Pedro Almodóvar, Bullfighting, Catholic Liturgy, Spanish Cinema. 


\section{INTRODUCCIÓN}

El cine de Pedro Almodóvar ha sido tradicionalmente considerado como un modelo de teatralidad en el séptimo arte. 1 Tanto es así, que los trabajos sobre este carácter no cesan, constituyéndose en un ejemplo de cómo las relaciones intermediales entre teatro y cine sigue siendo un tema aún por explorar en profundidad, y más cuando el propio concepto de teatralidad va variando a lo largo de los años, como lo demuestra el que el concepto de performatividad se haya ido imponiendo como paradigma analítico en muchos casos. La calificación del cine del director español como teatral es motivada por varias razones. Entre ellas, la más obvia es la adaptación en su filmografía de textos teatrales de diversa índole; pero también hay que tener en consideración una serie de ejemplos culturales, no relacionados tradicionalmente con el mundo de la escena, pero que "han sido incorporados tomando sus componentes más artificiosos" (Torre-Espinosa, 2017: 129). De esta manera, su cine se convierte en un ejemplo de disidencia respecto al modo de representación institucional (Burch, 1999), puesto que en el cine almodovariano la convención es colocada en un primer nivel en la puesta en escena, de igual forma que en el teatro más tradicional, evidenciando en consecuencia su marca autoral y rehuyendo la invisibilidad enunciativa.

Pero aun así, hay ciertos aspectos sobre este tema que no han sido aún abordados en la literatura académica, entre los que se encuentra la parateatralidad. Por este término vamos a entender a todas aquellas manifestaciones artísticas que, aun pareciéndolo, no son teatro. Son fruto de la mirada subjetiva del espectador quien, en lo teatral y en lo fílmico, experimenta "estéticamente [...] los movimientos del objeto percibido, es decir, de seguir corporalmente las variaciones del bailarín actor y la dinámica del espectáculo” (Pavis, 1996: 38). Además de este tipo de prácticas escénicas, José María Díez Borque afirmaba que hay manifestaciones artísticas que, sin ser teatro propiamente dicho, son representaciones que tienen un argumento (como puede ser el ballet o el mimo), pero también hay otros ejemplos que están "apoyados en una especial capacitación y potenciación de habilidades del actuante: circo, toros, deportes, que coinciden con el teatro en que se actúa, se hace algo para que los demás lo vean y/u oigan, aunque las diferencias sean de esencia, de modo que pueden estudiarse aislada o independientemente" (1988: 4). Es aquí, en este tipo de prácticas artísticas, donde se enmarcaría la parateatralidad.

Desde este punto de vista se pueden abordar diferentes manifestaciones más o menos relacionadas con las artes clásicas. Dentro de la filmografía de Almodóvar encontramos ejemplos como los role playing. En sus películas, en concreto, estos se llevan a cabo en el ámbito médico, como método pedagógico para enseñar cómo se debe actuar ante los tutores legales de un posible donante de órganos con muerte cerebral. El primer caso se corresponde con la película La flor de mi secreto, traído a colación de la visita que Leo, la protagonista, realiza a su amiga Betty para que le ayude a quitarse unos botines que le quedan demasiado apretados. Aquí vemos cómo Betty está dirigiendo una sesión formativa donde la enfermera Manuela simula la muerte de su hijo, y un par de profesionales le persuaden para que done sus órganos. El otro ejemplo de uso de

\footnotetext{
${ }^{1}$ La literatura académica surgida en los últimos años demuestra la salud de los estudios intermediales, especialmente los relativos a la relación del cine con las otras artes. Sobre el caso de la filmografía de Almodóvar al respecto, véase Abuín González, 2011, 2012; Forgione, 2003 y Torre-Espinosa, 2017, 2018a, 2018b.
} 
este tipo de parateatralidad en el cine de Almodóvar, mucho más significativo y complejo narrativamente que en el caso anterior, tiene lugar en la primera parte de la película Todo sobre mi madre, cuando Manuela - compartiendo nombre con la enfermera de La flor de mi secreto- actúa como actriz en una escena de role playing con el mismo objetivo que en la película anterior. Aquí lo llamativo es que la protagonista, en un irónico giro del destino, tendrá que vivir en la realidad lo que antes estaba simulando. Su hijo Esteban es atropellado y le piden que done sus órganos. Se muestra así, a través de la inserción en un nivel metaficcional de este simulacro formativo y su redundancia en la vida de la protagonista, un ejemplo de teatralidad extraescénica en la pantalla cinematográfica, donde se demuestra que la teatralidad puede derivarse de "manifestaciones teatrales que se producen fuera de los escenarios y que no tienen por qué ser la puesta en escena de un texto previamente escrito" (Pérez Bowie, 2010: 57-60). Estaríamos, pues, ante un claro ejemplo de parateatralidad fílmica.

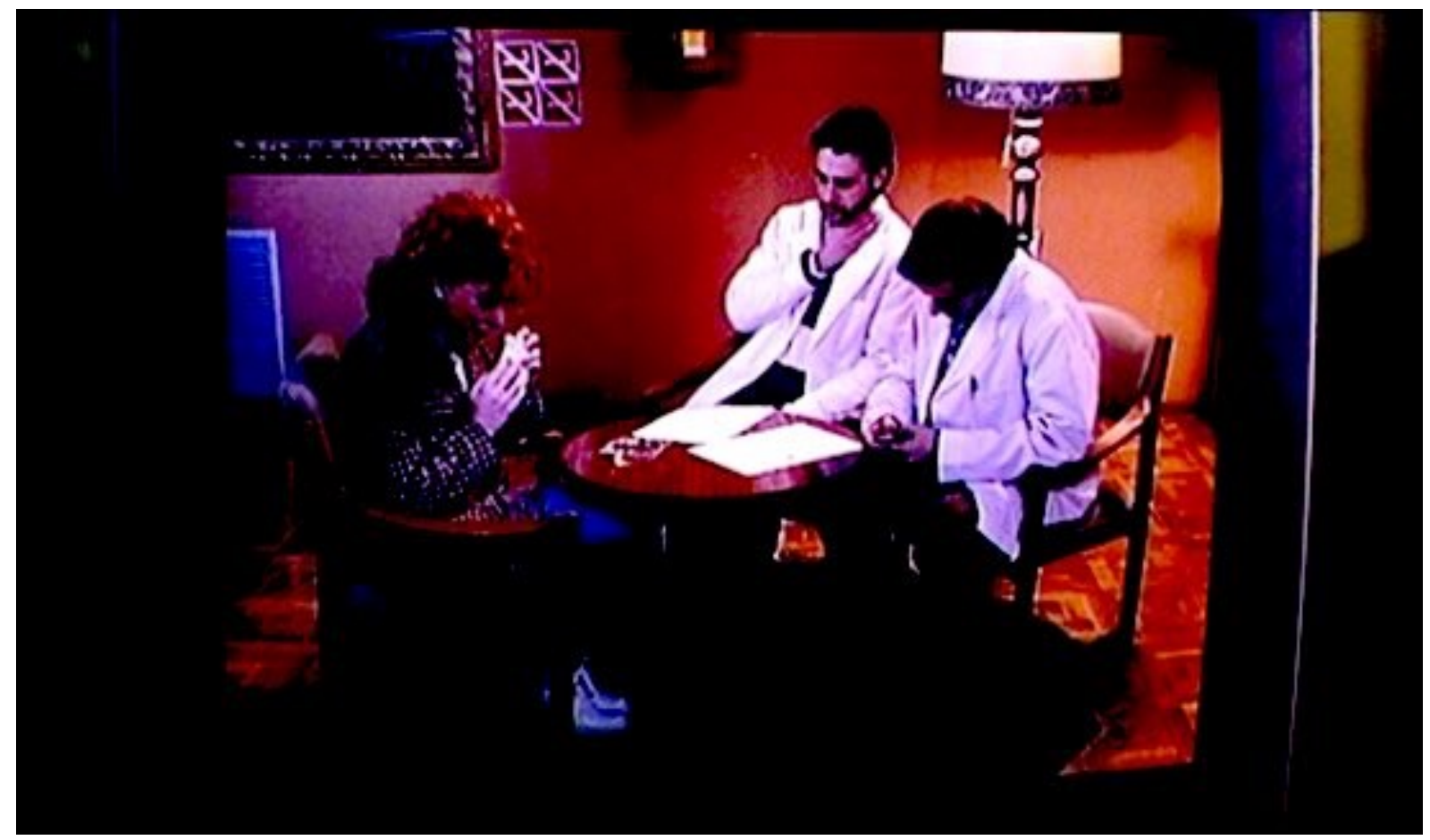

La flor de mi secreto (Pedro Almodóvar, 1995)

Además de este tipo de casos, podemos encontrar en su filmografía multitud de escenas en las que el mundo del toreo, de la danza, de la música o de lo litúrgico tienen una presencia notable. Pero también otro tipo de manifestaciones culturales, como puede ser el mundo de la moda, que aparece ya sea a través de desfiles en pasarela o bien con un vestuario que huye de la naturalización propia del cine mainstream. Además de esto, también consideramos como parateatralidad la utilización de obras pertenecientes a las artes plásticas que han sido deformadas para actuar a modo de telón de fondo teatral. El hecho de que los intérpretes "actúen" delante de estas obras artísticas les coloca en una posición similar a los cómicos del teatro. Y, por último, lo metacinematográfico, ya que en la mayoría de los casos supone una ruptura con el modelo del cine clásico, en cuanto se desvanece la invisibilidad enunciativa poniendo en un primer nivel el acto de enunciación, o sea, el cine como un constructo artificioso, filmado y proyectado en una pantalla. Es la ruptura con este modelo lo que convierte al cine de Almodóvar en un ejemplo más 
cercano a las producciones del cine del modo de representación primitivo, y su teatralidad (Burch, 1999), que al de Hollywood, por establecer una comparación evidente.

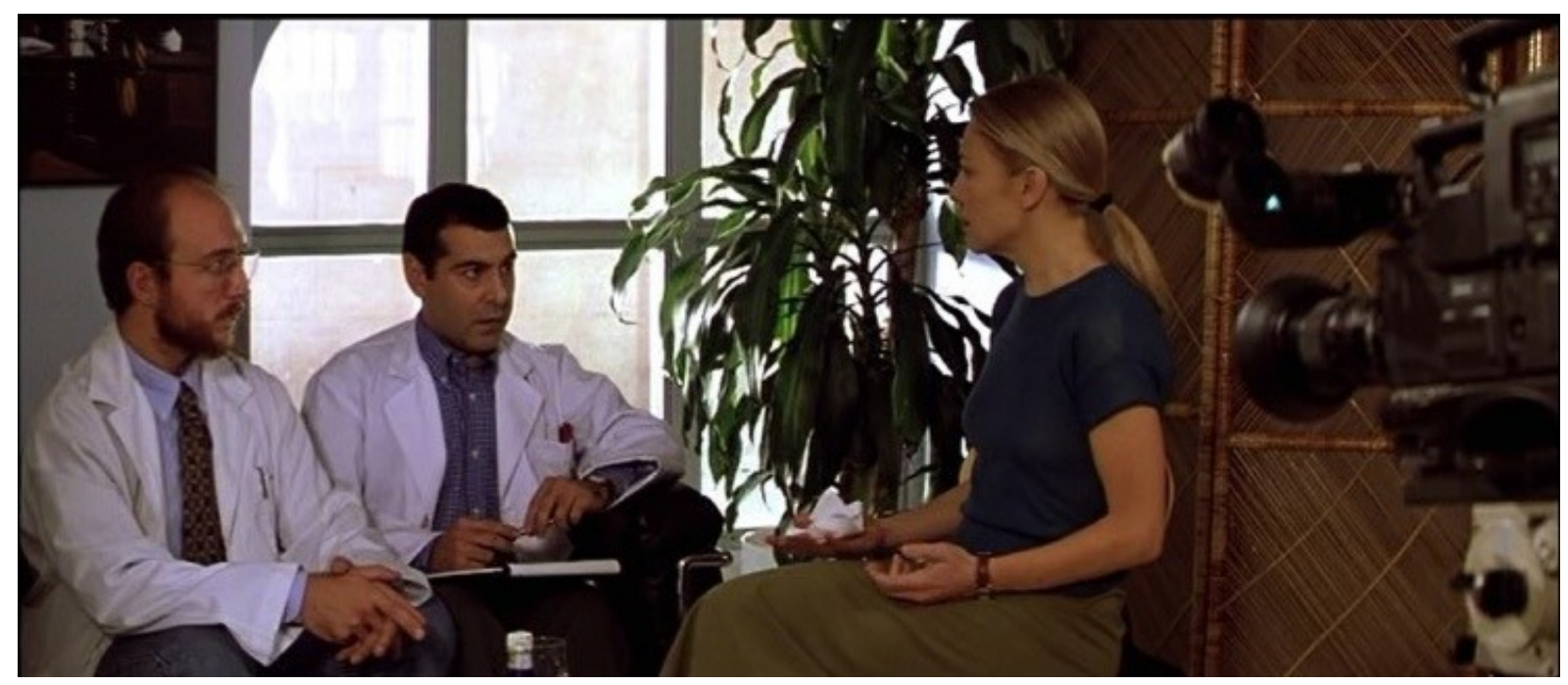

Todo sobre mi madre (Pedro Almodóvar, 1999)

En este artículo no pretendemos establecer una jerarquía entre las diferentes formas de parateatralidad, ni establecer límites de ningún tipo, - puesto que excede el objetivo de este trabajo- simplemente nos valemos de este concepto para agrupar aquellas formas de expresión donde actúa un individuo que depende de la existencia de un espectador para que su acción adquiera todo su valor comunicativo completo dentro del marco de la ficcionalidad. Son formas teatrales no canónicas pero que, sin lugar a dudas, al incluirse como modelo dentro del cine, proporcionan una teatralidad importante, como pueden ser también algunos rasgos escenográficos o tipos de vestuario que ejercen sobre el código cinematográfico una función teatralizante.

\section{METODOLOGÍA}

En este artículo se aborda el cine de Pedro Almodóvar desde una perspectiva comparatista entre diferentes formas parateatrales y las escenas en las que se hacen patentes en sus películas. Para ello, se ha llevado a cabo al visionado de sus filmes, procediendo a la identificación de la parateatralidad a través de sus intertextos, entendiendo este término en el sentido otorgado por Gérard Genette, es decir, "de manera restrictiva, como una relación de copresencia entre dos o más textos" (1977: 10). Una vez verificada la intertextualidad, se analiza su presencia en la película relacionándola, en su caso, con la trama de la película y explicando su forma de visualización y auricularización (Gaudreault y Jost, 1990), con el fin de explicitar las estrategias de inclusión en las películas y demostrar la naturaleza intermedial de estas obras fílmicas.

Se usará para el análisis los diferentes elementos constituyentes de la puesta en escena a partir de una síntesis de las categorías establecidas por Ramón Carmona (1996) y Patrice Pavis (1996): planificación, iluminación, escenografía, atrezo, vestuario, maquillaje, dirección de actores y banda sonora. Si bien la propuesta de Carmona se ciñe al fenómeno fílmico, la de Pavis permite establecer vínculos entre lo escénico y lo cinematográfico. De los elementos analizados, se 
consignarán en el presente artículo solo aquellos que mejor ejemplifiquen las estrategias empleadas en los filmes de Almodóvar, y se hará hincapié en los casos en los que la presencia de intertextos parateatrales se haya producido desde la descontextualización de la ideología propia correspondiente a ese tipo de prácticas en el ámbito cultural español. Como corpus de análisis se tendrá en cuenta su cortometraje Homenaje (1977), así como su filmografía completa de largometrajes hasta la fecha, puesto que en todos ellos podemos distinguir, en mayor o menor grado, ejemplos de parateatralidad. Nos gustaría advertir que, como ejemplos de parateatralidad, se han dejado fuera la danza y la música representada por haber sido estudiados con anterioridad con cierta profundidad (Deveny, 2005; Gutiérrez Albilla, 2003; Laferl, 2007; Poe, 2010; Rodríguez, 2004; Sánchez Noriega, 2017; Vernon, 2009).

\section{LA TAUROMAQUIA}

El mundo del toreo posee una serie de características que lo convierten en una forma de cultura de masas cuya popularidad se ha ido diluyendo con el paso del tiempo, aunque sin perder su capacidad de impacto en la sociedad. De ahí que los en otrora mitificados Rafael Gómez Ortega "El Gallo", Manolete o Joselito hayan sido relevados por toreros como José Tomás, un auténtico fenómeno si no de masas, sí de una fama inusitada. Vemos así que lo taurino, a pesar de su progresivo desplazamiento de la vida pública española, sigue mostrando una considerable influencia. Continúa existiendo una fascinación notable en torno al toreo como ritual, donde la muerte siempre se halla en el horizonte. El pulso mantenido en el ruedo entre el diestro y el toro, enfrentados cara a cara en el albero, genera una tensión dramática de resultado incierto. Se configura así en una especie de performance donde la única certidumbre que tienen los asistentes al comienzo es que dicho espectáculo se realizará de acuerdo a un código muy concreto determinado por su valor estético, donde el vestuario o la estructura de la corrida en tercios forman parte del mismo. El mundo taurino es visto así desde un plano simbólico, donde el torero, "si bien tiene mucho de actor, también lo tiene en no menor medida de sacerdote que oficia un rito" (Martín Arias, 2002: 36), convirtiendo a los espectadores en asistentes a un acto ceremonial. Se abre así una puerta a una religiosidad pagana, donde el toro adquiere cierto carácter de deidad, y donde la muerte es interpretada como sacrificio catártico.

Matador, de Pedro Almodóvar, es una de las películas que mejor ha recogido este carácter ritual. Un filme que, tanto en su argumento como en su puesta en escena -además del título-, integra el mundo de los toros de diversas maneras. Ya el arranque, durante los créditos iniciales, es bastante elocuente al respecto. En la televisión aparecen escenas de giallo italiano y cine de serie B (Jess Franco, por ejemplo), donde vemos y oímos a mujeres que van siendo asesinadas brutalmente. El televisor pertenece a Diego, diestro retirado tras una cornada y ahora profesor de toreo, que se está masturbando mientras ve estas imágenes. Se produce pues desde el comienzo una vinculación de la sexualidad a la muerte, una relación que alcanzará su grado máximo en el final de la película, y que muestra una relectura muy suigéneris por parte del filme, en cuanto el carácter castizo de la tauromaquia, y los valores asociados a la misma, es desplazado por su valor simbólico donde lo sexual es relacionado directamente con la práctica taurina, transgrediendo así su concepción tradicional. 


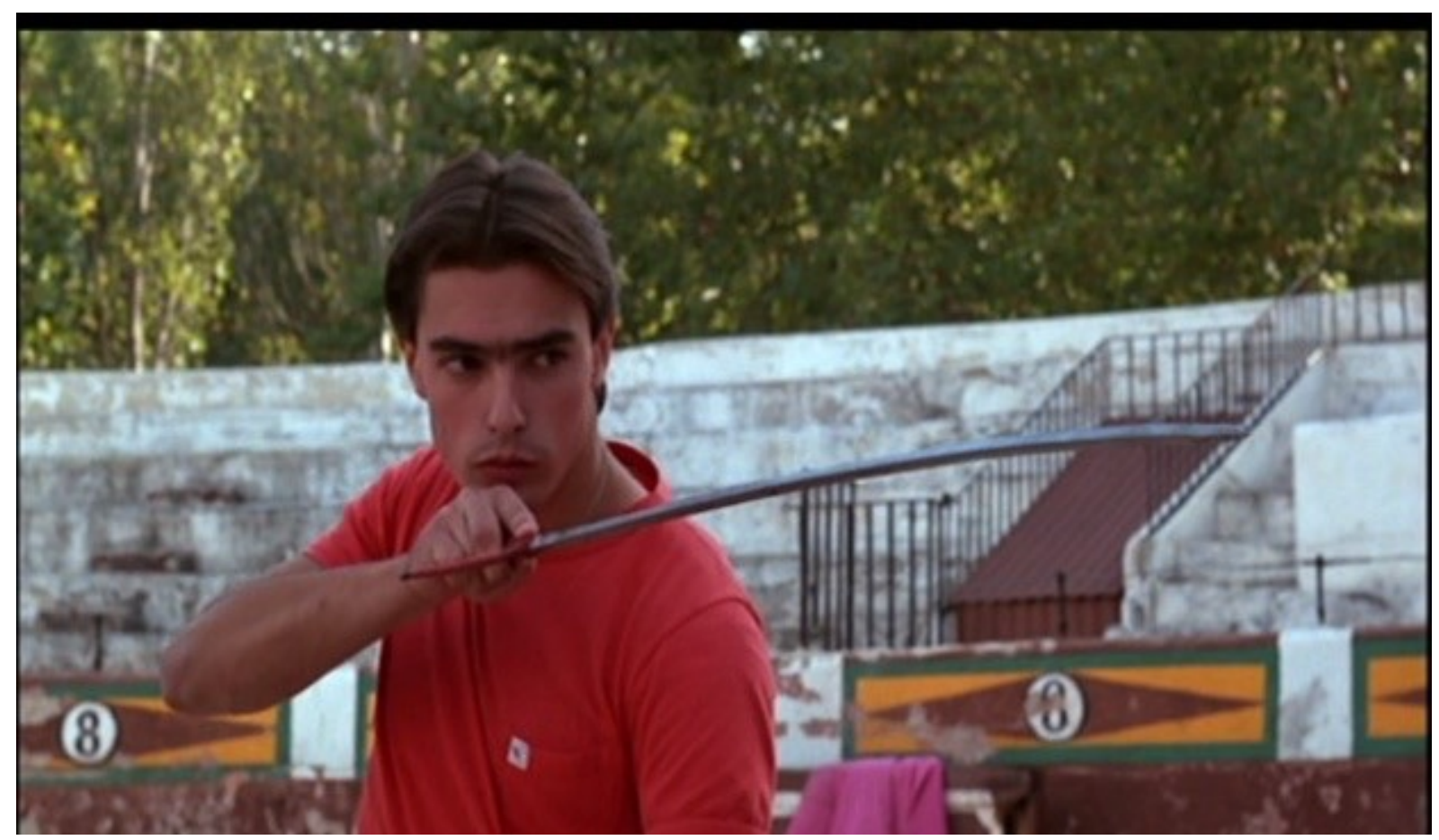

Matador (Pedro Almodóvar, 1986)

Lo más interesante se revela en la secuencia que sigue a los créditos, mientras Diego explica en la pizarra la importancia del estoque en una de sus clases, y cómo debe acometerse la aproximación al toro para emprender el lance final. En un montaje paralelo descubrimos cómo una bella mujer seduce a un hombre y se lo lleva a su casa para hacer el amor. Es María Cardenal, quien lleva un recogido voluminoso sujeto con un pincho en forma de estilete. Vamos viendo también, en este montaje paralelo, cómo los alumnos de Diego entrenan al aire libre. En el

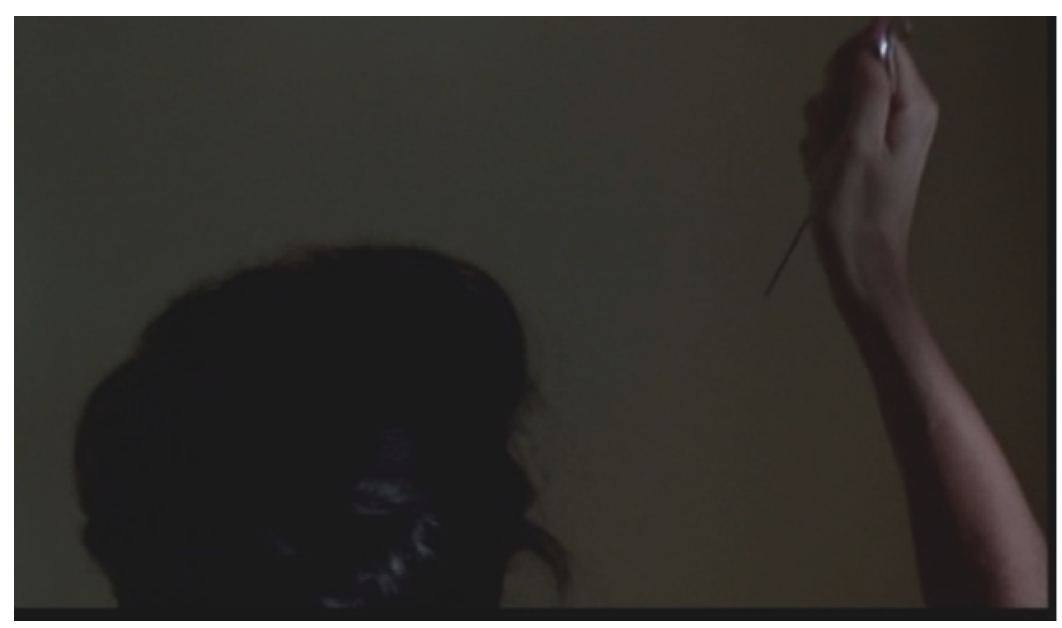

momento en el que uno de ellos va a practicar la estocada, María se quita su pincho y se lo clava en la nuca al joven como si de una puntilla se tratase. La secuencia acaba con el audio de Diego, quién concluye su explicación de esta técnica taurina diciendo: "Porque para matar a un toro bravo como él se merece, además de con la espada, hay que matarlo también con el corazón". Deviene esta introducción así en una prolepsis de lo que será el sentido de la película, donde el amor se convierte en un motor esencial para la vinculación del sexo con la muerte, y para la 
asociación de esta con la tauromaquia y su estética. La película acabará cuando Diego y María, amantes y en pleno acto sexual, decidan morir sobre un capote extendido sobre el suelo, a modo del último lance taurino.

Si en esta película observamos el uso del referente taurino, en su consideración más simbólica, aplicado a diferentes elementos del código cinematográfico —está presente en el argumento, por ejemplo, o en el vestuario, especialmente con la presencia de capas que simulan capotes taurinos-, será en Hable con ella donde se haga patente la vertiente espectacular de la tauromaquia mediante la visualización de fragmentos de dos corridas, algo que en Matador no ocurría. ${ }^{2}$ Lidia, una de las protagonistas, de nombre irónico y kitsch, es una torera que tiene que enfrentarse a una serie de obstáculos por su condición de mujer. La primera vez que aparece se encuentra en un programa del corazón en el que una presentadora vivaracha, disimulando al interesarse por su carrera en los cosos taurinos, le pregunta por su antigua pareja. Tras esta presentación, donde aparece en una visión hiperfeminizada, vestida con falda corta y estrecha y botas altas - lo que reta el carácter patriarcal propio del mundo de los toros en España-, aparece en la plaza en plena faena dando pases al astado. La cámara lenta se va recreando en la belleza de los movimientos de la matadora, que son realzados por la inclusión en la banda sonora del tema Por toda a minha vida, de Tom Jobim y Vinicius de Moraes, e interpretado por Ellis Regina. Es interesante ver cómo se procede a la fragmentación de la acción y cómo se elude insertar planos generales que asocien lo que vemos al punto de vista de los aficionados presentes en la plaza. Pero, en cambio, tanto aquí como en la escena siguiente, aparece el público mirando.

En la siguiente corrida de la película, en la que Lidia sufre una grave cogida que la dejará en estado de coma, se opta por mostrar planos de mayor amplitud (planos generales y planos enteros) y por una fragmentación menor en el montaje. Se busca así lograr el máximo realismo posible en la escena para que el momento de la cogida de la torera logre un mayor impacto. De ahí que se retrate el ambiente propio de este tipo de espectáculos, con planos donde se visualiza a la banda de música tocando sus cornetas, por ejemplo. Y lo que es más llamativo aún, se respeta en la mayor medida posible el punto de vista del espectador taurino. A pesar de existir planos cenitales que nos desubican de esta posición, la cámara se mantendrá a la altura de los espectadores desde la barrera, logrando así un verismo mucho mayor y favoreciendo que el público cinematográfico se identifique con ellos.

\section{LA LITURGIA CATÓLICA}

En el catolicismo, frente a la sobriedad de otras confesiones religiosas, los rituales ceremoniales que se llevan a cabo en sus celebraciones han destacado siempre por su suntuosidad. Existe una teatralidad clara con una división de roles y espacios dentro del mismo

\footnotetext{
2 Aun así, se puede contemplar ciertos rituales asociados al mundo taurino y que suelen permanecer ocultos para los aficionados al ocurrir en la intimidad. La preparación de Lidia para la corrida es mostrada de forma ceremoniosa, en completo silencio. La auricularización de la escena, que destaca los roces de la ropa sobre su piel, pretende sumergir al espectador en este ambiente íntimo. El ritmo solemne y cuasi documental que adquiere la escena aporta de esta forma también un aire premonitorio de la fatalidad que está por venir.
} 
edificio - iglesia habitualmente- donde el sacerdote actúa de oficiante y los fieles de público. ${ }^{3}$ La performatividad alcanza su grado máximo en el momento de la consagración de la hostia, en el que a través de la fórmula "este es el cuerpo de Cristo" la oblea se transfigura, a vista de todos y siguiendo la lógica de los speech acts de John Searle (1965), en una entidad significante de valor espiritual. Se impone así la liturgia como uno de los modos de teatralidad más importantes entre los existentes en la sociedad y fuera del mundo de la escena (Villegas, 1996). Desde este punto de vista, la misa se convierte en uno de los modelos usados para lo que sería el teatro-ceremonia surgido en el siglo XX. La religiosidad se configuró así, a través de su ejercicio público y colectivo y gracias a su posición central en diferentes marcos culturales, en una de las claves para la renovación de la escena, ejerciendo una interferencia nada desdeñable:

la ceremonia, justo por el carácter arcaico de sus lenguajes, que requiere unos lenguajes codificados, se muestra altamente afectiva y efectista; aún más que cualquier teatralización (empleo de lenguajes previamente codificados por el teatro, arcaicos por lo tanto), por cuanto que su llamada a lo simbólico (en mayor o menor medida aún vivo en el inconsciente del espectador), la dota de una dimensión emocional mucho más profunda que cualquier espectáculo de otro orden (Oliva y Torres Monreal, 1990: 409).

Las películas de Almodóvar demuestran su atracción por estas formas parateatrales al incluir elementos que remiten tanto a la liturgia como a la imaginería católica. Se da entrada así a un importante sesgo de teatralidad extraescénica muy interesante (Pérez Bowie, 2010: 58-60). Así, es habitual la presencia en los decorados de estas películas de retratos de santos o vírgenes, aunque siempre tamizados por una mirada pop. Esto es lo que ocurre en ;Átame!, donde un cuadro que preside el dormitorio contiene al Corazón de Jesús y a la Virgen María multiplicados por tres y en diferentes tonos cromáticos siguiendo la conocida técnica serigráfica de Andy Warhol.

El altar es otro de los elementos del culto religioso que aparece de diferentes maneras. Desde la más convencional, de forma denotativa solo para ambientar, como ocurre en la capilla del convento de Entre tinieblas, ${ }^{4}$ a otras formas que juegan con la transgresión, como sucede con la creación de altares paganos. Este último método es muy significativo por el proceso de remodelización que se lleva a cabo. En este nuevo Olimpo, ocupado por la mitología del siglo $\mathrm{XX}$, las estrellas cinematográficas vienen a suceder a los cuadros o figuras de los santos católicos. Ya en los cortometrajes de Almodóvar se puede apreciar este interés —o devoción- por figuras clave de la cultura de masas. Lo vemos en la pieza Homenaje, por ejemplo, donde se rinde tributo a Marilyn Monroe dedicándosele un altar. Este carácter sacrílego también estará presente en el ara que la Madre Superiora de Entre tinieblas alberga en su aposento, dedicado a las grandes pecadoras, asimiladas en este caso a mitos del celuloide como Brigitte Bardot, Ava Gardner o Zsa

\footnotetext{
3 "Pero todo se complica al internarnos en los terrenos de la fiesta, el rito, el mito visualizado, en los que puede darse una participación lúdica, profundamente inversora, o motivada e impuesta por altos ideales (procesiones y ceremonias), e incluso puede producirse la pura y simple contemplación” (Díez Borque, 1988: 49).

4 Otro ejemplo de uso denotativo del altar lo hallamos en Hable con ella. Antes de la corrida de toros donde Lidia resultará gravemente herida, vemos cómo su hermana se encomienda delante de una serie de estampas e imágenes religiosas, algo propio del ambiente del toreo: altares portátiles que viajan con los diestros durante toda la temporada taurina.
} 
Zsa Gabor. ${ }^{5}$ Yolanda, proveniente del mundo del espectáculo, se convertirá también en una de esas pecadoras por cuya alma reza la superiora. Ya su llegada al convento es muy significativa en torno a este carácter idólatra. Las hermanas deambulan en fila por la capilla entre los bancos, mientras cantan. $\mathrm{Al}$ recitar "Tú eres el camino para el alma bien" la puerta del fondo se abre. Una luz brillante inunda la entrada, silueteando la figura de la artista. Este halo luminoso que la rodea se convierte en metáfora de la fascinación cuasi sagrada que la monja sentirá hacia ella.
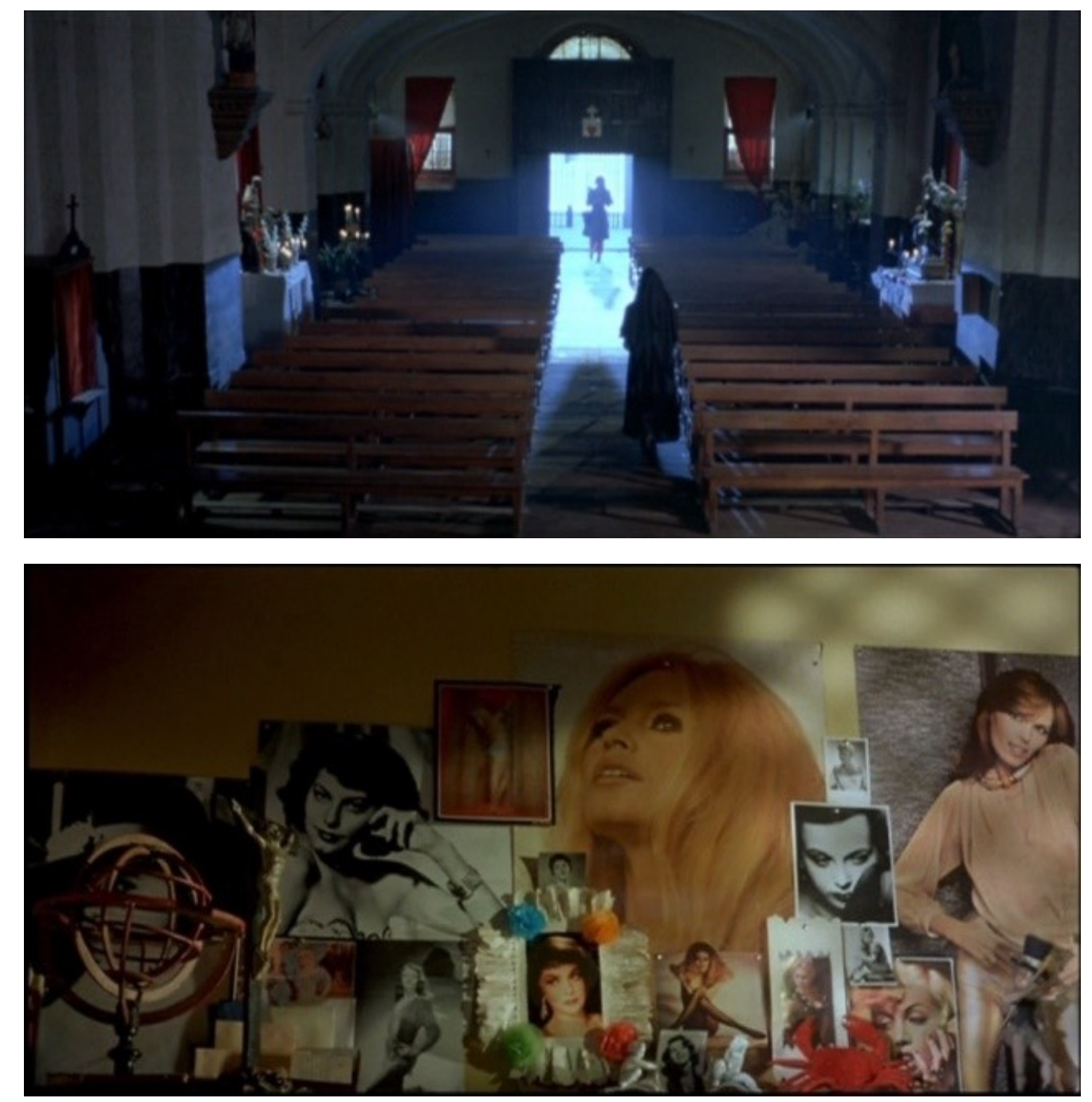

Entre tinieblas (Pedro Almodóvar, 1983)

Otra tipología de altar la hallamos en La ley del deseo o en Los amantes pasajeros, donde se adopta también un carácter absolutamente kitsch, asociado a lo camp en cuanto además se enmarcan dentro de una estética queer. Si en la comedia citada Fajas se encomendará en un altar portátil a San Juan Bautista, la Virgen del Pilar y diversas deidades hindúes, en cambio en el drama un recargado retablo lleno de figuras, tanto religiosas como paganas, le servirá de telón de fondo para construir un tableau vivant que recuerda a una pietá gay. Será hacia el final de la película, cuando Pablo sostenga entre sus brazos el cuerpo inerte de Antonio, y el altar comience a arder,

\footnotetext{
5 Esta cinefilia es mostrada en varias películas y siguiendo diversas estrategias. Puede ser constatable también en Tacones lejanos, a través del álbum que la madre del juez Domínguez confecciona con recortes de prensa.
} 
como metáfora del deseo exacerbado que inunda la película y que estalla en esta última parte del metraje.

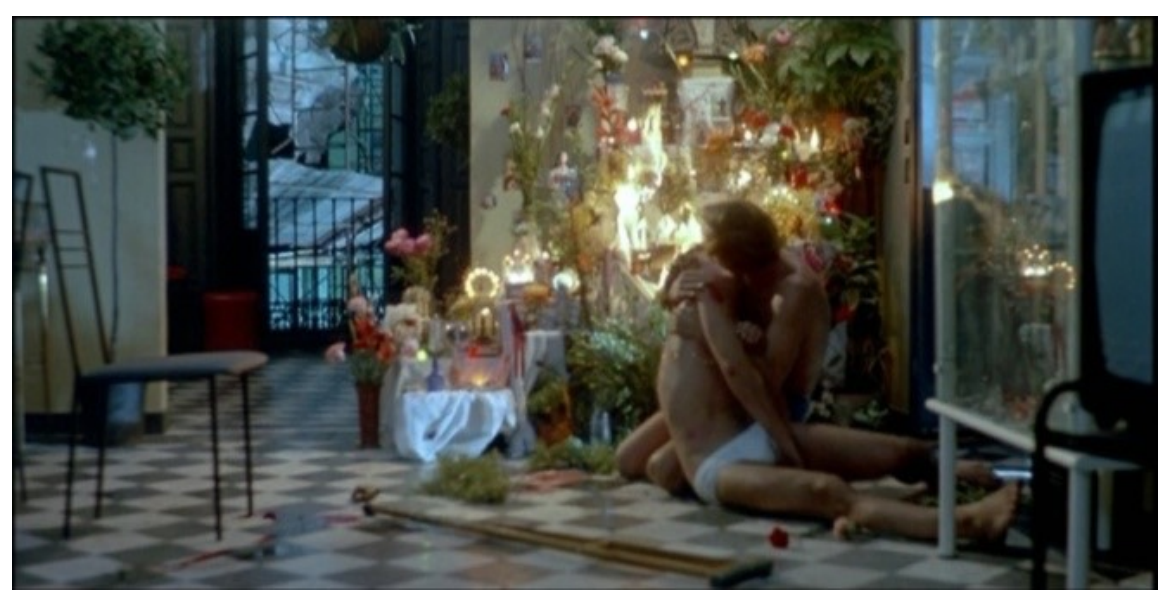

La ley del deseo (Pedro Almodóvar, 1987)

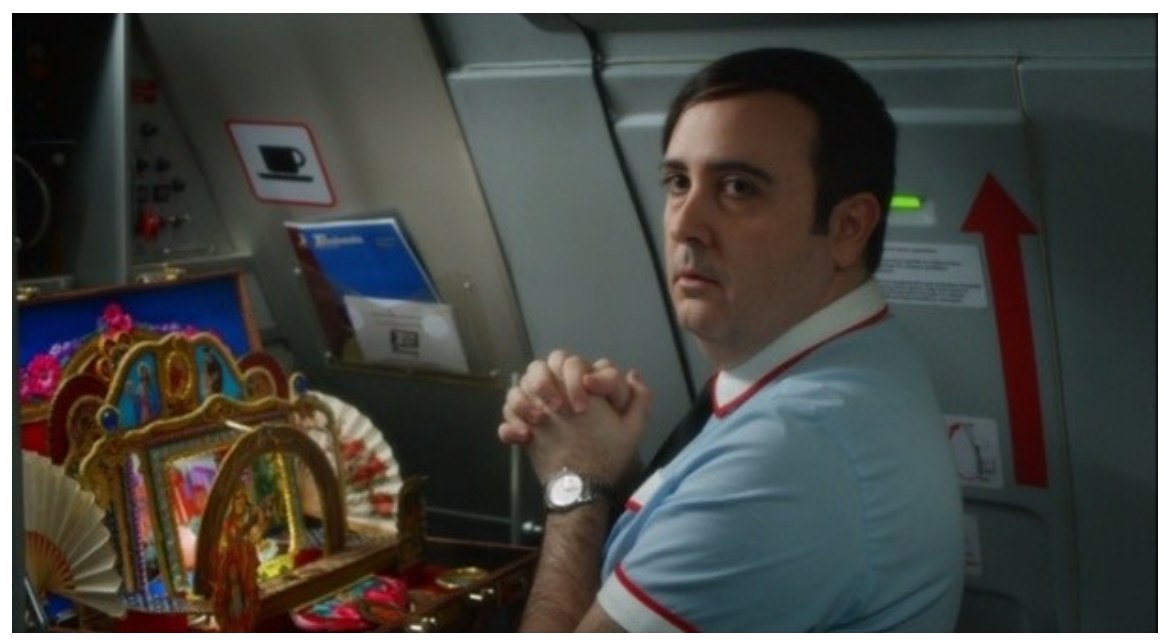

Los amantes pasajeros (Pedro Almodóvar, 2013)

El último ejemplo que vamos a reseñar aquí tiene lugar también en esta película. Tina, transexual, pasea con su hija Ada y pasa por la calle donde está el colegio donde estudió cuando era niño. En la capilla suena el órgano, y decide entrar. Allí está tocando el mismo sacerdote que la abandonó cuando era alumno. Tina comienza a cantar la letra de la canción religiosa que toca el clérigo, avanzando hacia el órgano. En esta escena, filmada en un plano medio de larga duración, tanto la espontaneidad de la cantante como la ausencia de respuesta por parte del cura acercan esta acción a la del musical. Pero, sobre todo, la introducción de este fragmento es una rememoración del pasado, de una infancia vinculada al modelo del nacionalcatolicismo español y que se pretende reescribir en un sentido más libérrimo, con relaciones amorosas homosexuales en el seno de la Iglesia que apuntan hacia la pederastia - como sucede, en este sentido, con la reelaboración de esta escena en La mala educación-. Este tipo de cantos forma parte de la educación sentimental de toda una generación de españoles, entre los que se encuentra Tina. El rito, una vez más y en un sentido muy diferente, vuelve a hacerse presente: “'All rites interest me', he says, 'especially the Catholic ceremonies as theatre, but the military doesn't"' (Almodóvar en Tóibín, 2001: 249). Estos filmes de Almodóvar constituyen un desplazamiento claro respecto a la representación habitual de la religión en la cultura española. En su discurso, se acerca a ciertos 
intereses artísticos donde la moral tradicional no tiene cabida, propiciando de esta forma relecturas queer o camp tan originales como identificativas del cine almodovariano.

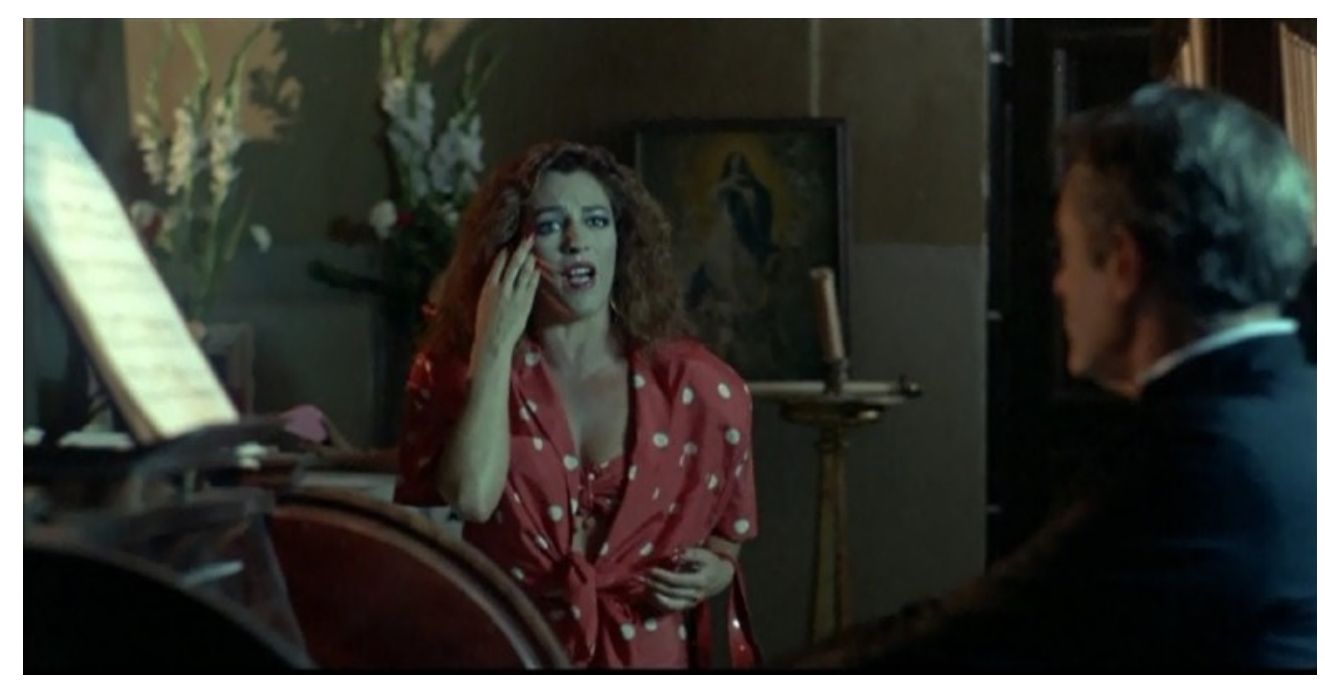

La ley del deseo (Pedro Almodóvar, 1987)

\section{EL ARTE DISTORSIONADO}

La pieza artística, al aparecer como cita dentro de una película, adquiere un nuevo carácter. Así ocurre en las películas de Almodóvar, en las que estas obras actúan como hipertexto (Genette, 1977) del mundo de las artes plásticas, estableciendo un diálogo de interesantes repercusiones. Esto es especialmente notable en sus primeras producciones, donde de igual manera que se retrata la realidad musical, se hace lo propio con las diferentes manifestaciones artísticas del momento. Estamos hablando de lo propio de la Movida madrileña, con una estética

muy influenciada por el arte pop, en particular por Andy Warhol, quien tuvo a bien incluso hacer una visita a Madrid, en 1983, para exponer en la sala Vijande. Y un poco antes, en la Fundación Juan March había expuesto su trabajo Roy Liechtenstein. Inspirados por estos y otros artistas pop internacionales, la expresión plástica de la Movida se caracterizó por su colorido y sus excesos iconográficos, que pretendían ser rompedores aunque a veces tenían más de esperpento que otra cosa (Lechado, 2013: 224).

En este contexto, Los Costus se convirtieron en referentes fundamentales, no solo por su producción artística, sino también porque su piso se convertiría en el epicentro para parte de la contracultura madrileña. Entre esta troupe se encontraba Almodóvar, quién incluso rodaría en esta casa parte de Pepi, Luci, Bom y otras chicas del montón. Tanto los cuadros que aparecen, como la propia presencia de los artistas trabajando, introducen un elemento de autorreflexividad sobre el proceso de creación artística al ser mostrados sus mecanismos de construcción. Pero lo más importante desde una perspectiva visual es que estas piezas de arte serán filmadas teniendo en cuenta su valor expresivo, especialmente en lo referente a su valor escenográfico, ya que se seleccionarán los encuadres teniendo en cuenta la composición del plano respecto a estas piezas de arte. Se emplean pues estas obras, de artistas con los que comparte amistad y afinidad estética, a modo de telón teatral de fondo, configurándose en una especie de escenografía. Así, en Laberinto de pasiones vemos cómo el dormitorio de Sexilia está decorado con murales de Guillermo 
Pérez Villalta, o cómo en otra casa aparece un estudio cuyas paredes están cubiertas por retratos fotográficos de Ouka Leele. Este carácter teatral será así mismo reforzado por una planificación muy frontal y una composición en el plano muy estática, sin movimientos de cámara que doten de dinamismo a la película. ${ }^{6}$
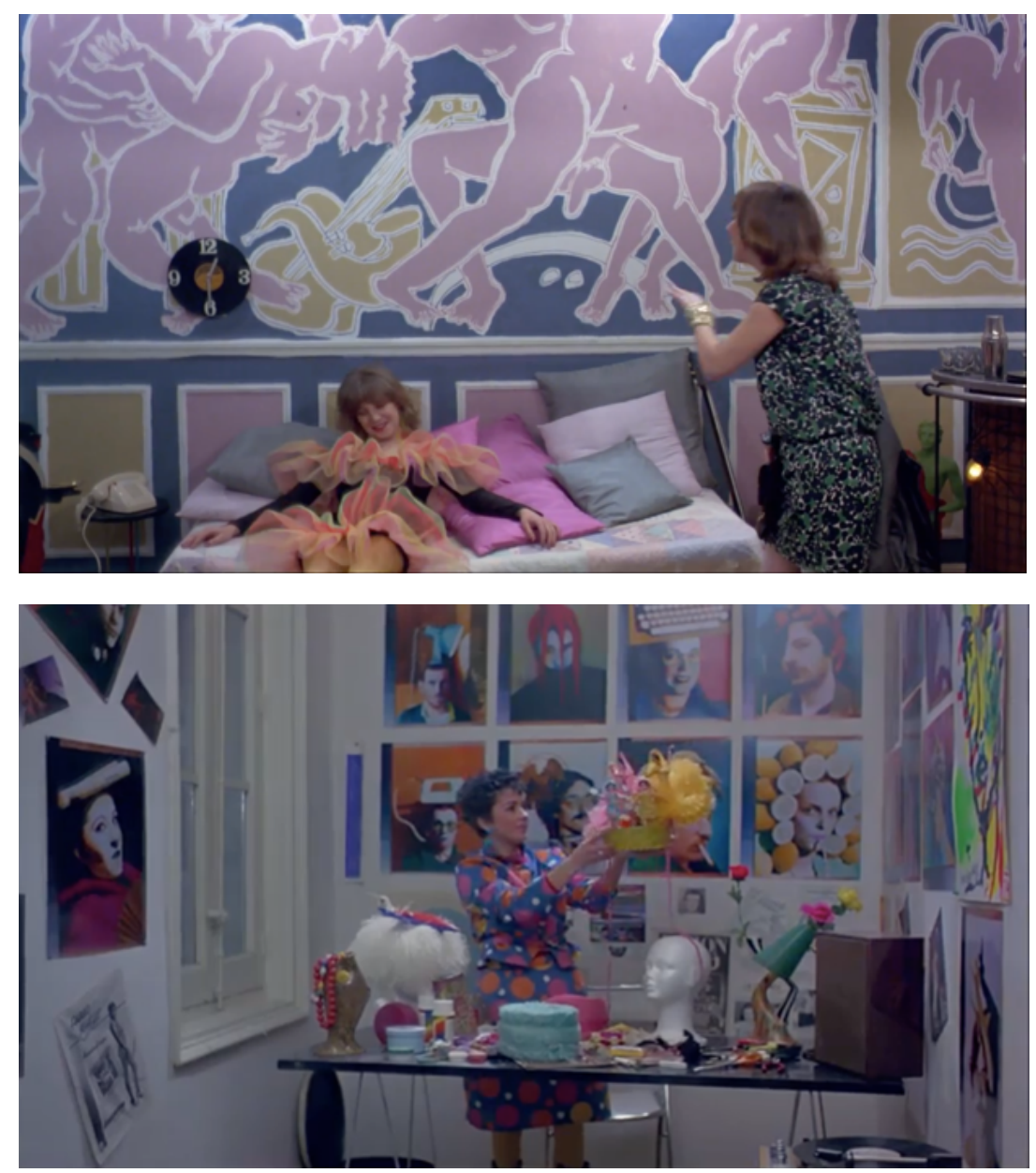

Laberinto de pasiones (Pedro Almodóvar, 1982)

Pero encontramos un caso más interesante aun cuando las obras de arte son además modificadas para crear un efecto sugestivo sobre el espectador. Estamos hablando de la reproducción de óleos de pintores clásicos como Tintoretto o José de Madrazo, cuya ampliación es usada para provocar una sensación de aberración sobre la imagen cinematográfica. Al ser modificadas sus proporciones originales se convierten en una especie de telones pintados. Así, esta reteatralización posmoderna del cine (Pérez Bowie, 2010) es introducida en películas como Carne trémula, en la que vemos cómo las paredes de la entrada del piso de Helena están ocupadas por pinturas de gran tamaño. Al entrar Víctor en la casa, en la secuencia en la que resultará herido el policía David, una panorámica hace que fijemos nuestra atención en las dos pinturas,

\footnotetext{
${ }^{6}$ En todo el cine de Almodóvar es posible encontrar obras de arte contemporáneo. Un ejemplo lo hallamos en el despacho de Enrique Goded en La mala educación, donde, en sus paredes, podemos ver una obra de Dis Berlin. O bien la pieza Dionisos encuentra a Ariadna en Naxos, de Guillermo Pérez Villalta, presente en La piel que habito.
} 
deteniéndose en ambas y dándoles una importancia capital, ya que actuarán de fondo durante la posterior escena del forcejeo y disparo.
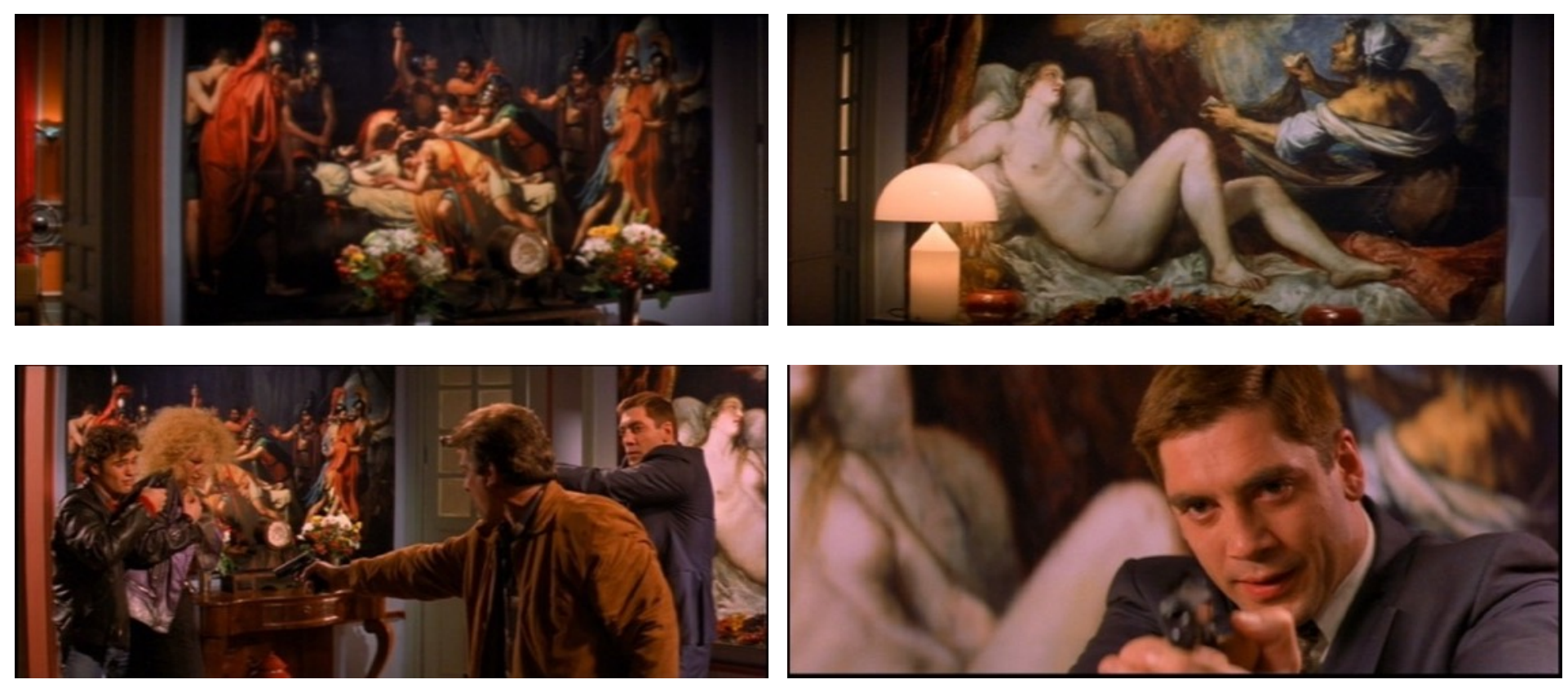

Carne trémula (Pedro Almodóvar, 1997)

Otro ejemplo mucho más claro del uso de la ampliación de la pintura con un doble objetivo, introducir teatralidad al actuar como telón de fondo y provocar desasosiego con esta deformación aberrante, lo hallamos en Los abrazos rotos. En esta película Lena va sintiéndose cada vez más encarcelada dentro de su propia vida, debido a que Ernesto Martel, su marido, la va sometiendo a un enclaustramiento progresivo. En un travelling que va de derecha a izquierda vemos una pared de la casa con unas pinturas de gran tamaño, de inspiración pop y con armas representadas ${ }^{7}$. Al finalizar el movimiento descubrimos a Ernesto y Lena cenando. La pared de atrás es ocupada por un bodegón de grandes dimensiones: la ampliación de Manzanas, de Juan de Espinosa. Cuando se levantan y él la abraza por detrás se observa cómo todo el fondo lo ocupa el lienzo. Se produce así una reteatralización de la escena, un recurso propio de la Posmodernidad y que autores como Peter Greenway han explotado recurrentemente: el de usar poca profundidad de campo con un decorado detrás ocupado por una o varias piezas de arte. ${ }^{8}$

\section{EL CINE DENTRO DEL CINE}

En el cine de Almodóvar la intertextualidad es un rasgo muy característico, siendo el séptimo arte en este sentido uno de los discursos artísticos con mayor presencia. Numerosas películas aparecen de diferente forma a lo largo de su filmografía, pero la cita (Genette, 1982) se

\footnotetext{
${ }^{7}$ Estas y otras serigrafías de armas de fuego serán usadas a lo largo de todo el metraje, y relacionándolos siempre a la figura de Ernesto padre o Ernesto hijo. Las vemos a través de planos muy frontales, con poca profundidad de campo, en cuyo centro se ubican los personajes y cuyo fondo es ocupado por este tipo de cuadros. Se trata de la serie Pistolas, de Andy Warhol, presentada en la madrileña sala Vijande en 1983.

${ }^{8}$ Este mismo recurso será usado en La piel que habito con pinturas de Venus que actúan como símil del caso de Vera, como ocurre con la Venus de Urbino de Tiziano.
} 
ha convertido en el método preferido para llevar a cabo esta integración de intertextos. Se convierten así estas películas en un desafío para el público cinéfilo, dispuesto a sorprenderse descubriendo asociaciones fílmicas sean del tipo que sean. Este sería el caso de Eva al desnudo (All about Eve, Joseph L. Mankiewicz, 1950) en Todo sobre mi madre, donde además de citarse se asocia con la historia de Manuela.

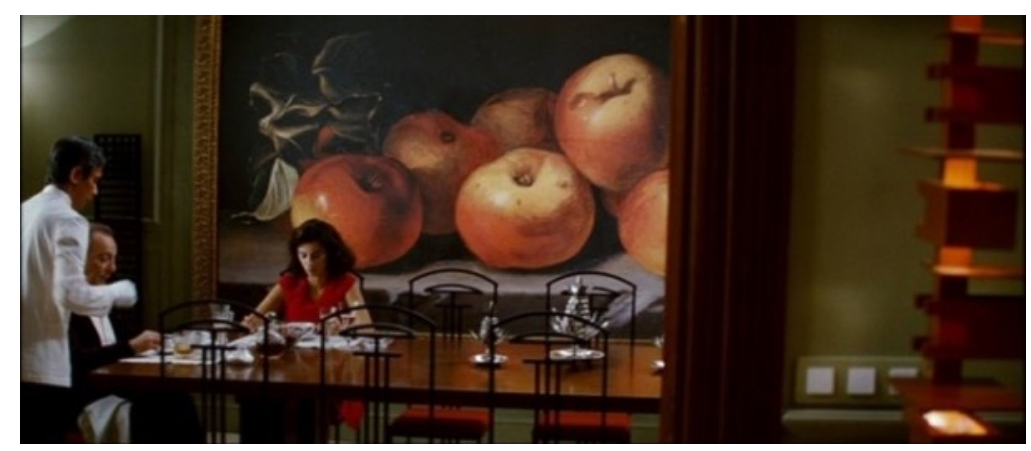

Los abrazos rotos (Pedro Almodóvar, 2009)

Pero entre las peculiaridades que singularizan sus películas se encuentra también su naturaleza metacinematográfica, que va más allá de la simple inserción de fragmentos de otros filmes. En estas películas podemos encontrar numerosos casos de mise en abyme, donde el propio proceso de filmación aparece en la diégesis. Se establecen así diferentes niveles narrativos en la historia, llegando a lo metaficcional en numerosos casos. Entre las posibles modalidades empleadas en este tipo de mecanismos fílmicos se halla lo que Christian Metz denominó grado simple de "filme en el filme" (1991: 2), una variante que sirve para nombrar aquellas estructuras narrativas en las que descubrimos que lo que hemos visto es lo filmado en la diégesis fílmica.

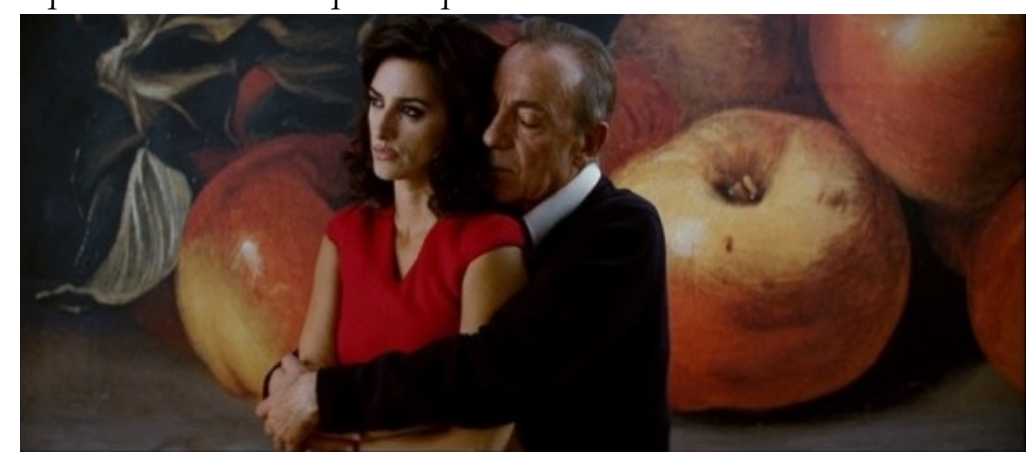

Los abrazos rotos (Pedro Almodóvar, 2009)

La mala educación es la película donde este aspecto alcanza su grado máximo, con una estructura en forma de matrioshkas rusas que progresivamente nos va desvelando en qué nivel narrativo se halla lo que estamos visionando. Lo interesante es que este desvelamiento se produce al filmarse el proceso de enunciación de las imágenes que habíamos visto con anterioridad. Es así como descubrimos que la historia de Zahara, que hacía minutos que estábamos viendo, no es más que parte de un largometraje de ficción que está rodando Enrique Goded. Lo conocemos al ver el contracampo de lo que aparece en pantalla, en la secuencia en la que los sacerdotes la asesinan. El espacio profílmico lo ocupa ahora el equipo de rodaje (ayudante de dirección, script, técnico 
de sonido, producción, pertiguista, director...), desvelando que todo lo que habíamos visto con anterioridad no era más que una ficción enmarcada. ${ }^{9}$

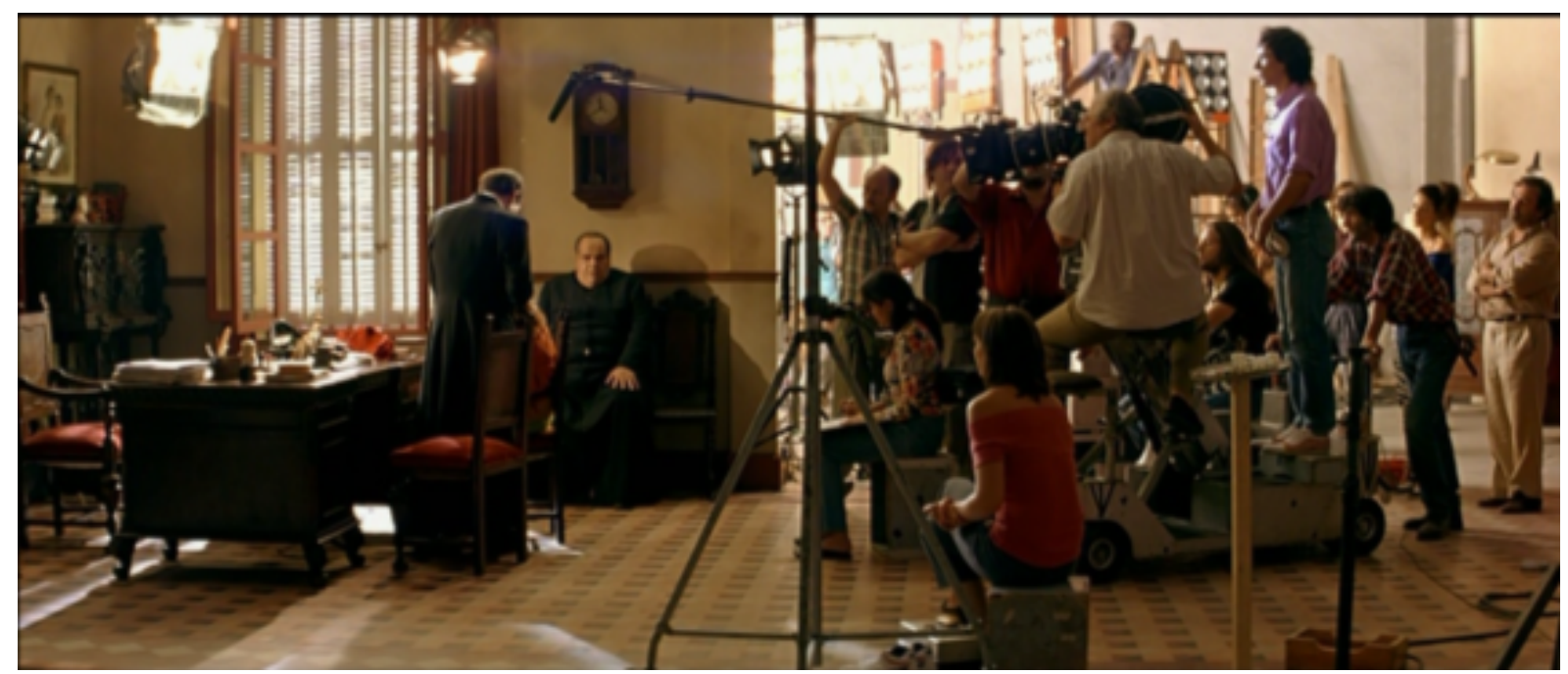

La mala educación (Pedro Almodóvar, 2004)

Algo muy similar ocurrirá en Los abrazos rotos, aunque aquí la estructura del guion no pretende crear falsas expectativas. Esta intencionalidad es manifestada ya desde su arranque, donde aparecen algunos créditos de inicio sobreimpresionados sobre la imagen del monitor de un combo durante un rodaje. Vemos el trabajo del equipo en torno a una doble de luces ${ }^{10}$, cuyo lugar será ocupado con posterioridad por la actriz real, Lena, que comienza a ser dirigida en el set por Mateo Blanco. Se revela así un aspecto muy poco conocido por el público, esta imagen de referencia que suele tener el director $-\mathrm{y}$ otros miembros del equipo- durante la filmación.

Con posterioridad, y en diferentes secuencias, presenciamos el rodaje de la película Chicas y maletas, y más interesante aún, también asistimos al montaje de esta película, un filme dentro del filme que es creado además "ante los ojos del espectador" (Ivánov, 1981: 27) al mostrarnos el propio proceso de creación fílmica. Esto dará pie a que hacia el final de la película se realice un curioso ejercicio autorreflexivo, cuando descubramos que el fracaso comercial de esta película protagonizada por Lena se debió a un malintencionado montaje encargado por Ernesto Martel para vengarse de ella. La película pasa de ser un drama más o menos convencional a adquirir una cierta complejidad metadiscursiva. Se pone en primer plano el proceso de construcción fílmica, exponiendo cómo un montaje puede arruinar la trayectoria profesional de un actor al seleccionarse unos planos en detrimento de otros — se seleccionaron las peores tomas de Lena-, o al manipular el tempo narrativo en una dirección incorrecta —el primer montaje de esta película no respetaba el ritmo propio de la comedia-.

\footnotetext{
${ }^{9}$ El proceso de rodaje ya estaría presente en sus primeras películas. En el arranque de ¿Qué he hecho yo para merecer esto! Gloria, la protagonista, atraviesa una plaza que es usada como set cinematográfico, y que está ocupada por un equipo de rodaje. Gloria entra dentro del campo profílmico que ese equipo está rodando, pasando a integrarse en un doble nivel narrativo. Algo parecido podría decirse de la inclusión en la misma película del rodaje de una dramatización de La bien pagá, en un playback cantado por el propio director.

10 Profesional del cine que se coloca en el lugar del actor o actriz protagonista para montar el plano (distancia focal, luz, movimientos...).
} 
Se produce así un fenómeno de "reflexividad cinematográfica" (Pérez Bowie, 2005: 126-37) que busca reforzar el carácter ficcional del hecho fílmico. En este momento los personajes en la pantalla devienen en actores, los objetos filmados en atrezo, los edificios en decorados... Con esta apología de la idea del cine como constructo se produce a su vez una exaltación de la enunciación, rompiendo con la idea del meganarrador de Gaudreault y Jost (1990), cuya identidad difusa, y habitualmente invisible, es asociada al discurso del cine clásico hollywoodiense. ${ }^{11}$
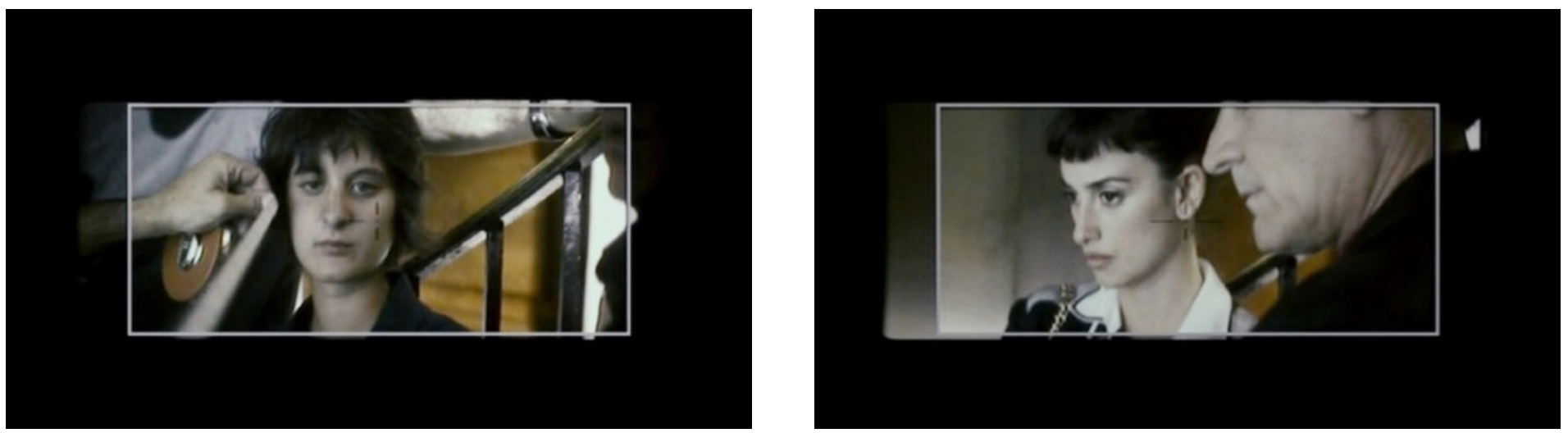

Los abrazos rotos (Pedro Almodóvar, 2009)

Esta misma idea de explicitación del proceso de creación fílmica podemos extenderla a otro de los elementos más llamativos dentro del cine de Almodóvar, y es la presencia del trabajo de doblaje. Este recurso se convirtió en una de las señas de identidad de la exhibición cinematográfica en España, al obligarse a doblar las películas extranjeras. Esta medida, de motivación ideológica -lograr una unidad lingüística nacional-, provocó que el público asimilara este método y lo convirtiera en la forma natural de consumo del séptimo arte. El cine de Almodóvar, en cambio, articula en torno a este hecho un discurso crítico muy significativo. En lugar de ideologizarlo, aludiendo a su origen franquista, reflexiona sobre la entidad de la imagen cinematográfica y su sonido, desmontando el efecto naturalizador del doblaje para revelar su carácter de artificio. La imagen que estamos viendo en la pantalla cambia su sentido en el momento que vemos que esas voces que oímos no han sido registradas en el momento de la filmación. Más aún, ni siquiera les corresponde. Se produce así un cuestionamiento de la narrativa clásica hollywoodiense, que acarrea además una expansión de la teatralidad hasta configurar un theatrum mundi en tanto que ni siquiera la realidad profílmica sonora es real, sino inventada durante el proceso de posproducción.

Esto último lo podemos problematizar en torno a un par de secuencias pertenecientes a dos películas. La primera de ellas pertenece al inicio de La ley del deseo. Un hombre joven y atractivo, en un dormitorio, va respondiendo a las peticiones de un señor de mayor edad que le pide que se desnude y se masturbe. Hemos de esperar a que la escena avance para descubrir que lo que estamos viendo se corresponde con las imágenes proyectadas durante una sesión de doblaje. El aspecto físico de los dobladores rompe con el efecto de realismo que hasta ese

\footnotetext{
11 Otro ejemplo interesante es el de la pieza El amante menguante presente en Hable con ella. Se filma un cortometraje como si se tratara de una película de cine mudo, provocándose un interesante efecto. Tomando prestadas las palabras de Christian Metz, el "filme segundo es un concentrado metafórico del otro" (1991: 3). Así, mediante este recurso, se produce la elipsis de la violación de Alicia por Benigno.
} 
momento tenía el filme. Se introduce además un guiño irónico, puesto que el aspecto del atractivo protagonista de la película que se está doblando no tiene nada que ver con el físico del doblador, un señor de mediana edad y poco agraciado físicamente. Vemos así lo fácil que es suplantar identidades, tema que será desarrollado más adelante con el deseo amoroso como motor de las acciones.

El otro ejemplo se corresponde con la película Mujeres al borde de un ataque de nervios. Pepa e Iván son dos actores, además de examantes, que se dedican también al doblaje. En el comienzo de la película vemos cómo él dobla una famosa escena de Johnny Guitar (Nicholas Ray, 1954), una desgarradora secuencia donde el desamor es el centro de la propuesta. Al cabo de las horas, Pepa dobla su parte, produciéndose a través de la voz un emotivo reencuentro sonoro, pero que en realidad solo sirve para demostrar la creciente distancia que media entre ellos, capaces únicamente de comunicarse a través del teléfono - como en La voz, humana de Jean Cocteau- o bien mediante el doblaje de una película, sin tenerse el uno enfrente del otro. Las palabras de súplica declamadas por Iván durante el doblaje de Johnny Guitar se convierten así en un puro artificio, reforzado al mostrar todo el dispositivo técnico involucrado en su trabajo.

La complejidad de esta técnica nos hace ver cómo se produce una confluencia metaficcional (Abuín González, 2005) que, si bien no emplea intertextos teatrales, sí pone de manifiesto los mecanismos empleados para la consecución del efecto de verosimilitud. Se produce una disociación entre imagen y sonido que dinamita los presupuestos de verosimilitud del cine clásico, obligando al espectador a asumir un pacto de ficción similar al activado durante el proceso de la denegación teatral, en palabras de Anne Ubersfeld el "funcionamiento psíquico que permite al espectador ver lo real concreto sobre la escena y adherir a eso por ser real, sabiendo (y no olvidando sino por cortos instantes) que ese real no continúa fuera del espacio de la escena" (2002: 32). Sigue así la tendencia instaurada en su cine, según la cual, en palabras de Gonzalo Navajas, se opone a la historia y procede a la invalidación de la realidad extratextual, concordando con el estereotipo moderno de la degradación de la objetividad y la supravaloración de lo subjetivo y autorreferencial. Se entienden así las múltiples referencias al cine, la exposición del cine dentro del cine: rodaje incluso en otro rodaje, el videoclip, los carteles de películas, etc. Solo el lenguaje y los medios fílmicos parecen legítimos y valiosos (Navajas, 1996: 292).

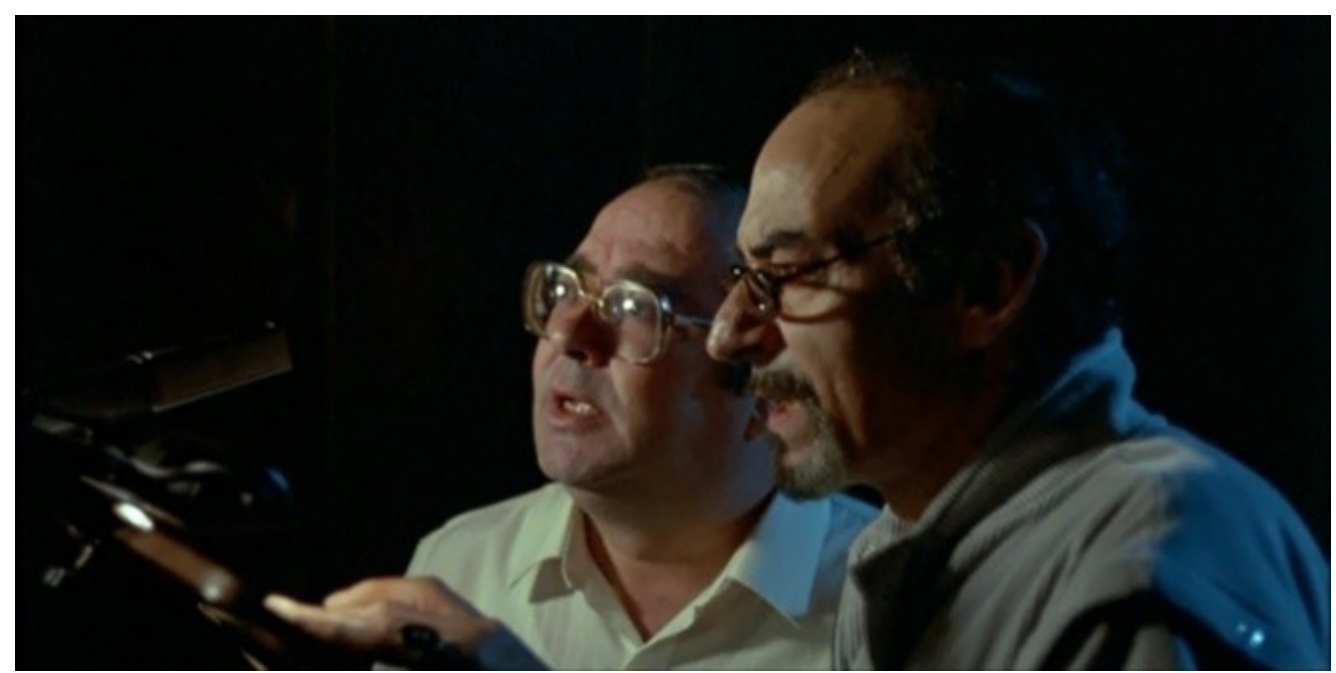

La ley del deseo (Pedro Almodóvar, 1987) 


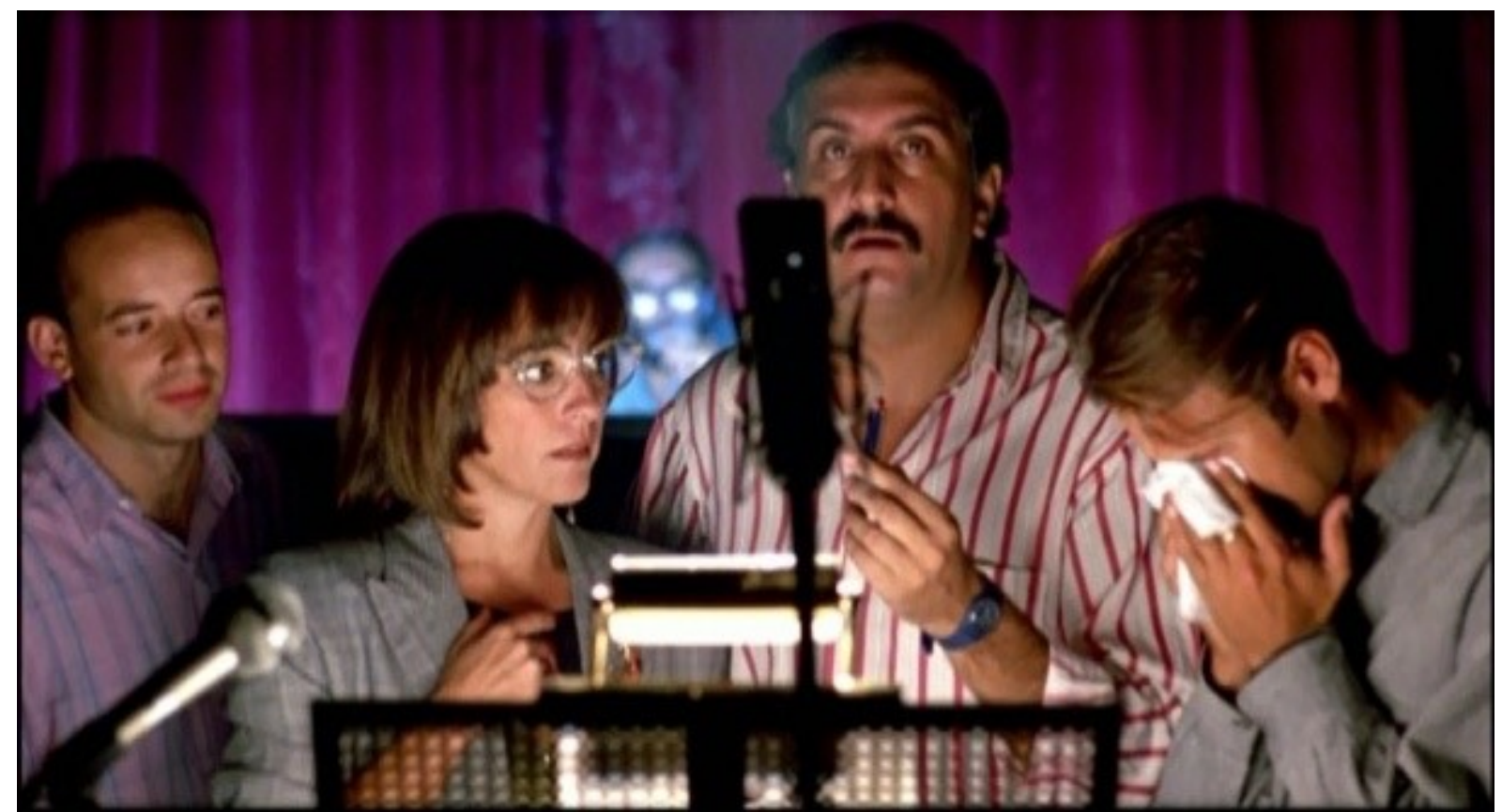

Mujeres al borde de un ataque de nervios (Pedro Almodóvar, 1988)

\section{LA SEMANTIZACIÓN DE LA MODA}

Si el vestuario, tanto en las artes escénicas como en el cine, se convierte en un elemento crucial para la caracterización de los personajes, dentro del paradigma de la Posmodernidad se configura además en una de sus manifestaciones discursivas más novedosas e influyentes. Se trata de un producto de la cultura de masas que ha perdido su carácter elitista para pasar a crearse, en el sentido de Walter Benjamin, en una producción serializada. Su propia funcionalidad tradicional ha sido desplazada, adoptando el tono lúdico y hedonista propio de la hipermodernidad según la determinó Gilles Lipovetsky: "Lo chic, la distinción, quedan cursis por ello; el prêt-à-porter ha suplantado la alta costura en la dinámica viva de la moda. Lo que substituye al buen gusto, al gran estilo, es lo 'divertido': la edad humorística ha acabado con la edad estética" (Lipovetsky, 1983: 151). Dentro de este marco se podría interpretar la nueva dimensión que tomó el mundo de la moda en los años de la Movida, con la que estuvo siempre muy relacionada (Lechado, 2013: 88). Dejaba de ser un asunto exclusivo de las clases altas de la sociedad para sufrir un proceso de democratización paralelo al que se estaba produciendo en la sociedad a un nivel político.

Así surgió durante aquellos años el fenómeno "Moda de España", auspiciado por las autoridades políticas, para quienes esta actividad estaba cargada de un enorme potencial en la proyección exterior del país. La moda llegó en aquella década prodigiosa a todos los rincones y se convirtió en poderosas empresas y en centro de debates que, incluso, alcanzaron las más altas instancias educativas: entre sus más señeros representantes, Adolfo Domínguez llegó a dirigir cursos de verano en la exigente Universidad Internacional Menéndez Pelayo. De esta manera, invitando al consumo de la imagen, ídolo por antonomasia de la posmodernidad, la moda rendía culto al imperio de lo efímero (Martín de la Guardia, 2011: 164-165). 
En las películas de Almodóvar la moda ocupa un lugar esencial. Además de contribuir a la caracterización de los personajes, opera en un tono carnavalesco, en el sentido bajtiniano y siguiendo la estela de realizadores como Fellini. Una celebración de la vida en la que el vestuario se convierte en un elemento de gran expresividad. Así hay que entender el uso de la ropa en sus primeras películas, donde el hedonismo que se vivía en Madrid en aquellos años se manifiesta en las vestimentas y peinados de los personajes de la contracultura que pueblan sus filmes, despreocupados por ceñirse a los cánones tradicionales. En estas películas actúa a modo de reflejo de la Movida madrileña, con su querencia hacia manifestaciones pop y punk. Así se puede ver por ejemplo en Pepi, Luci, Bom y otras chicas del montón. El vestuario usado en la película es el mismo que usaban en su vida diaria. Esto lo constatamos a través de las fotos promocionales o la portada del disco del grupo Alaska y los Pegamoides. Vemos cómo Bom viste en el filme igual que Alaska en su día a día, e incluso comparten el mismo peinado, con coletas laterales y superiores, de igual manera, a su vez, que uno de los personajes de Grease (Randal Kleiser, 1978).
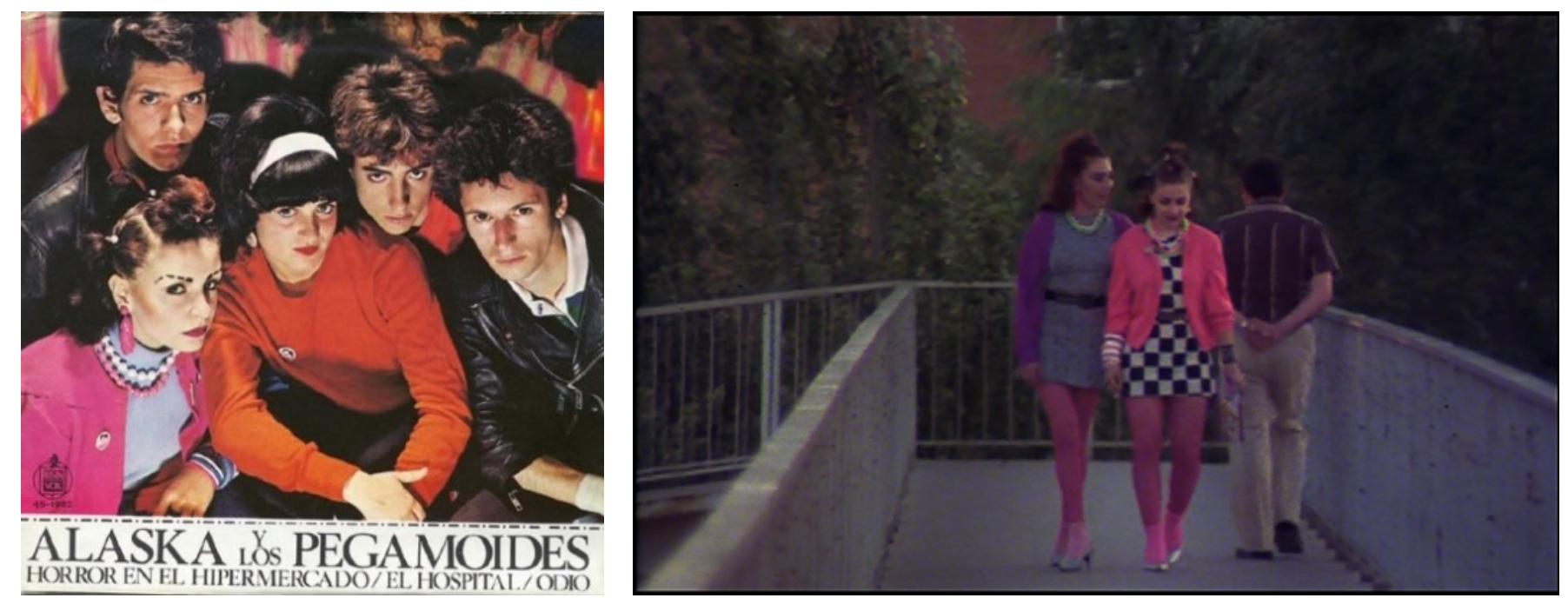

Foto promocional de Alaska y los Pegamoides y secuencia final de Pepi, Luci, Bom y otras chicas del montón (Pedro

Almodóvar, 1980)

Aunque en estas primeras películas se usa el vestuario de los propios actores o de los amigos del director, en las siguientes películas se contará con la colaboración artística de diseñadores de renombre. Si Jean Louis fue el responsable del vestuario de grandes películas del Hollywood dorado como Imitación a la vida (Douglas Sirk, 1959), siguiendo la estela de diseñadores como Travilla que configurarían esa imagen prototípica del glamour hollywoodiense, Jean Paul-Gaultier o la firma Chanel serán reclamados por el director manchego para sus creaciones, haciendo indisociable a partir de este momento personajes y vestuario en muchas de sus películas.

La transición hacia este modelo de la alta costura y el prêt-à-porter es evidente en Matador. En esta película asistimos a un desfile donde el personaje de Eva va a trabajar como modelo. En el backstage vemos al propio Almodóvar encarnando al diseñador, que se llama Francisco Montesinos en alusión al famoso modisto. E incluso Pilar, la madre de la maniquí, se paseará sobre las tablas con paso decidido, como si estuviera desfilando. Se realiza así un guiño irónico al mundo de la moda en España, en plena ebullición en ese momento. 

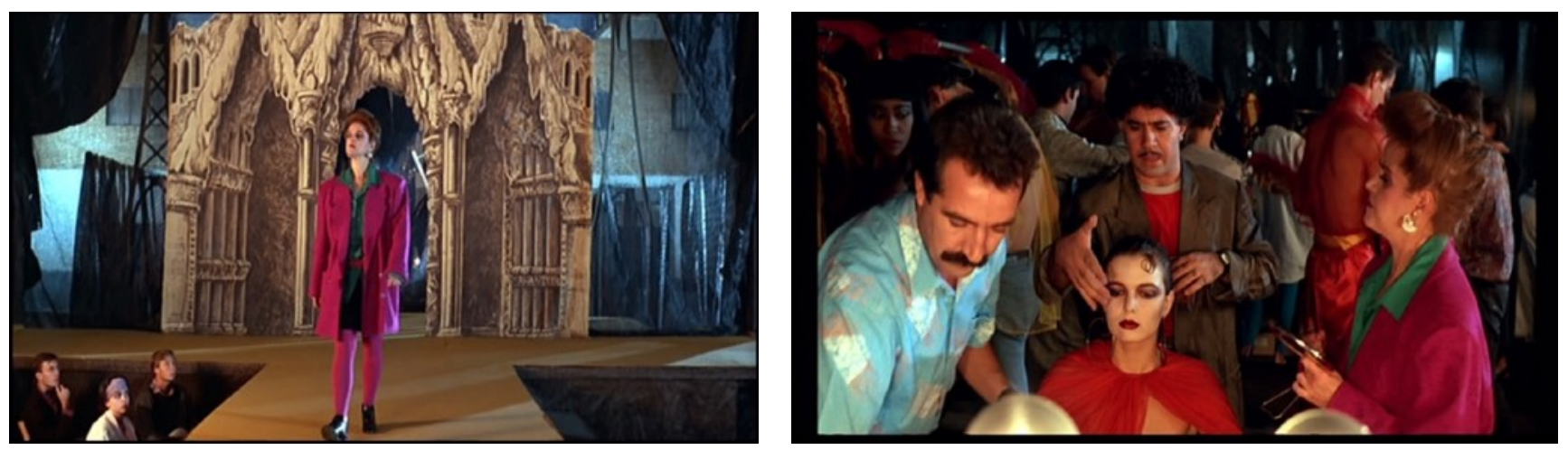

Matador (Pedro Almodóvar, 1986)

Pero no solo en este sentido irónico aparece el mundo de la moda, sino que además habrá una reinterpretación a través del camp, cuya teatralidad y artificialidad hará que el vestuario se cargue de ironía y se trasforme en traje de escena (Sontag, 1964). Así hay que interpretar el vestido de Sexilia en Laberinto de pasiones, que será revisado en Kika y más tarde en el traje de Zahara en La mala educación. En estas prendas, unos pechos falsos quedan al descubierto. Se realiza así un uso no realista de este elemento del código cinematográfico, el vestuario, que lo acerca al mundo de la escena. Se pone de relieve un significado que trasciende la caracterización psicológica o social del personaje para lograr una espectacularización de la ropa, que simplemente por su visión cause cierto impacto entre el público. Y todo dentro de la lógica del humor almodovariano, que gusta del disfraz, la máscara y el artificio para poner en jaque las convenciones sociales, y de esa forma disolver ciertos preceptos rectores de la moral de la época.

Además de recurrir al sexo en esta primera etapa, se usarán otro tipo de estrategias que, mediante la transgresión, logren sorprender a los espectadores. Esto ocurre con el personaje de Sor Víbora en Entre tinieblas. Aficionada a la costura, la monja ha diseñado trajes de auténtica vanguardia para renovar la imagen anquilosada de las esculturas religiosas del convento. Surge así un elemento irreverente que recuerda al desfile eclesiástico de Roma (Roma, 1972), de Federico Fellini. La liturgia católica, con su pompa habitual, es satirizada así a través de la moda.
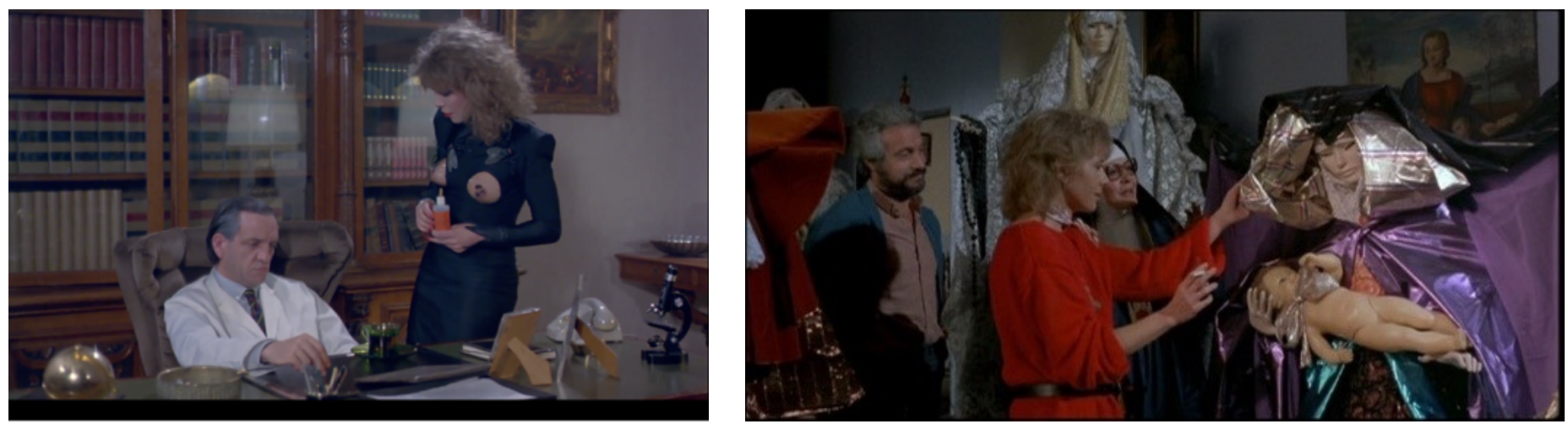

Laberinto de pasiones (Pedro Almodóvar, 1982) y Entre tinieblas (Pedro Almodóvar, 1983)

Además de usarse la ropa con este objetivo humorístico, hallamos también otros usos que ayudan, de forma más o menos velada, a entender la gravedad de ciertos aspectos argumentales de la historia. Un ejemplo de esto lo encontramos en Los abrazos rotos. En una escena en la que se 
preparan para una cena, Ernesto Martel coloca unos collares dorados de bisutería a Lena. Esas joyas, de tamaño exacerbado, además de denotar glamour y un alto nivel económico, actúan como metáfora de la relación opresiva y angustiosa que mantienen, ya que estas alhajas no dejan de ser cadenas. Sirve así para reforzar el carácter posesivo de él y su deseo de convertirla en una mujer florero mermando para ello su libertad. ${ }^{12}$ Vemos pues cómo en las películas de Almodóvar el vestuario adquiere un significado que trasciende al de la mera funcionalidad, siendo la teatralidad uno de las consecuencias principales de este fenómeno.

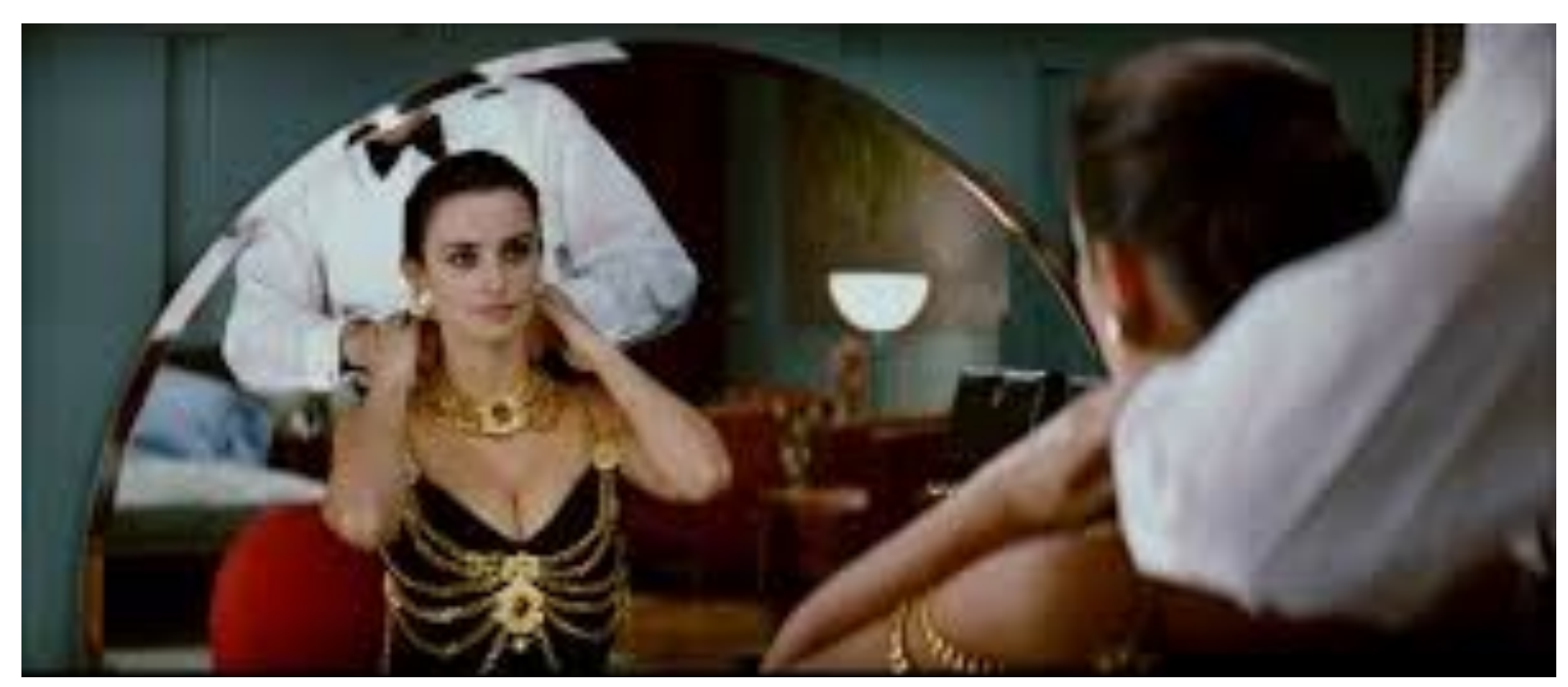

Los abrazos rotos (Pedro Almodóvar, 2009)

\section{CONCLUSIONES}

Si la filmografía de Almodóvar ha sido vista como teatral es por un lado a la tendencia al artificio de sus imágenes y tramas, lo que le acerca al ámbito de la convención teatral más que al de la representación aparentemente no mediada de la realidad profílmica, propia del cine más comercial. Pero, también, esta teatralidad acaece por la amplia presencia de intertextos teatrales y parateatrales en su cine, como se hace patente en sus películas. Tanto es así que en todos sus largometrajes podemos ver ejemplos de esto último, siendo el cine dentro del cine el elemento más importante tanto por su presencia como por las implicaciones narrativas que conlleva, seguido del arte distorsionado, la liturgia católica y la tauromaquia. Encontramos así que los casos analizados aquí, o bien otros que remiten al mundo de la danza o de la música escenificada, son integrados dentro de la diégesis fílmica propiciando un nivel de lectura adicional a las imágenes y sonidos mostrados en la pantalla.

En todos los ejemplos aquí consignados observamos la copresencia de dos factores, básicos también en la configuración de las prácticas espectaculares, y que son el actuante y el

\footnotetext{
12 Se puede además establecer una lectura de esta escena desde un punto de vista sociológico: "En el orden burgués la mujer, pasiva, es un indicativo del poder económico y social de su marido. Su ociosidad, así como el lujo de sus vestidos y joyas, denotan riqueza y una posición acomodada. La mujer se exhibe como objeto-florero, es una creación más del hombre, que es quien dicta las normas estéticas que rigen el atuendo femenino" (Cruzado Rodríguez, 2004: 44).
} 
espectador junto a algunos elementos escenográficos que remiten al código teatral. La conjunción de estos elementos hace que las películas se carguen de una gran performatividad, especialmente en los casos en los que el dispositivo fílmico es expuesto en un primer nivel narrativo, como pueden ser las escenas sobre rodajes.

El reconocimiento por parte del espectador de la calidad artificiosa de estas películas se produce pues al romperse la invisibilidad enunciativa propia del modo de representación institucional (Burch, 1999) o cine clásico. Además de por los artificios propios de la estética almodovariana, esto se produce por la inserción de intertextos parateatrales que ponen en evidencia la composición heterogénea de sus filmes. La presencia de elementos metacinematográficos, asimismo, provoca que el significante fílmico haga referencia a sí mismo, rompiéndose el efecto de verosimilitud tal y como se ejerce en el cine mainstream, y obligando al espectador a un nuevo pacto ficcional donde la convención debe ser ahora asumida conscientemente.

Resulta también muy significativo el origen de los elementos del repertorio cultural que han sido usados para llevar a cabo sus películas, ya que indica una clara internacionalidad a la hora de seleccionarlos. Encontramos así obras o autores que pertenecen al ámbito cultural español, como puede ser el mundo del toreo o la liturgia católica, pero también otros de diferente tipo, como se puede ver en Hable con ella, una película que abre y cierra con intertextos de la coreógrafa alemana Pina Bausch. Se demuestra así como en la filmografía de Almodóvar se usan modelos pertenecientes a diferentes sistemas culturales de forma totalmente integradora, mostrando la capacidad de este cine de constituirse en receptor de múltiples interferencias. Y, además, de resignificarlas adecuándolas a su Weltanschanung, como ocurre con la liturgia católica o la tauromaquia, cuya representación se efectúa alejándose de las normas de uso en la tradición cultural española, asociados a unos valores y a una moral conservadora que es puesta en entredicho con estos filmes.

Como consecuencia, observamos que el gusto por la inclusión de lo parateatral en su filmografía contribuye a reforzar la visión theatrum mundi propia de su cine, donde la representación tiene un valor fundamental y donde el artificio es propuesto como modelo de conocimiento, muy en consonancia con la estética posmoderna a la que el director español ha sido adscrito tradicionalmente por la crítica. Y, además, sin ocultar la heteroglosia de su escritura fílmica. Los diversos discursos que tienen cabida en su obra son fruto de una visión sobre el mundo del arte donde el artificio se muestra en primer plano, algo buscado por el propio autor: "lo que me encanta es esa parte de artificio que corresponde al trabajo del director. En ese artificio es donde puedes plasmar todas tus intenciones de director" (en Strauss, 2001: 27). Esta visión da como resultado un cine con una gran capacidad intermedial, "dentro de una técnica que es autorreferencial, y que se ha convertido en un estilo propio” (Urios-Aparisi, 2010: 264). Y todo ello, para reflexionar sobre el amor, el deseo o la familia como escenario de representación de emociones y sentimientos. 


\section{BIBLIOGRAFÍA}

ABuín GonzÁLEZ, Anxo. "El filme de teatro: arte frente a industria, o totus mundus agit histrionem". Anthropos: buellas del conocimiento 208 (2005): 138-151.

ABuín GonzÁlez, Anxo. "Almodramas, o lo tuyo es puro teatro: el teatro en el cine de Pedro Almodóvar". Boletín Hispánico Helvético 17-18 (2011): 105-125.

Abuín GonZÁLEZ, Anxo (2012). El teatro en el cine. Madrid: Cátedra.

BurCH, Nöel (1999). El tragaluz del infinito: contribución a la genealogía del lenguaje cinematográfico. Madrid: Cátedra.

Carmona, Ramón (1996). Cómo se comenta un texto fílmico. Madrid: Cátedra.

Cruzado Rodríguez, Ángeles (2004). "El fetichismo o la fragmentación del cuerpo femenino en el cine: Eyes wide shut". ArRIAGADA Flórez, Rodrigo; ESTÉVEZ SAÁ, José Manuel y SiLVA ECHETO, Víctor (ed.). Sin carne, representaciones y simulacros del cuerpo femenino: tecnología, comunicación y poder. Sevilla: Arcibel: 44-59.

Deveny, Thomas. “'Déjenme llorar' (y reír): la música en Hable con ella de Pedro Almodóvar”. España Contemporánea: Revista de Literatura y Cultura 1 (2005): 69-83.

DíEz BorQue, José María (1988). Historia del teatro en España II. Madrid: Taurus.

Forgione, Anna Pasqualina (2003). Spiando Pedro Almodóvar. Il regista della distorsione. Nápoles: Giannini Editore.

GAUDREAUlT, André y JOST, François (1990). El relato cinematográfico: cine y narratología. Barcelona: Paidós, 2001.

GENETTE, Gérard ([1977] 1989). Palimpsestos: la literatura en segundo grado. Madrid: Taurus.

GutiérRez AlbiLla, Julián Daniel (2003). "Cuerpo, silencio y movimiento. La integración de Café Müller de Pina Bausch en Hable con ella”. Zurian HernándeZ, Fran y VÁzQueZ VARELA, Carmen (coords.). Almodóvar: el cine como pasion: actas del Congreso Internacional "Pedro Almodóvar". Cuenca: Universidad de Castilla La Mancha: 383-392.

Holguín, Antonio (1994). Pedro Almodóvar. Madrid: Cátedra, 2006.

IVÁNOV, Viacheslav V. ([1981] 1998). "El filme en el filme". Filme(s) en el film: el intexto fílmico. Valencia: Episteme: 18-32.

LAFERL, Christopher F. (2007). "El interés por la música latinoamericana: de Lorca a Almodóvar". Simson, Ingrid (ed.). América en España: Influencias, intereses, imágenes. Madrid, Frankfurt: Iberoamericana, Vervuert: 137-171.

LECHADO, José Manuel (2013). La Movida y no sólo madrileña. Madrid: Sílex.

LIPOVETSKY, Gilles ([1983] 2000). La era del vacio: ensayos sobre el individualismo contemporáneo. Barcelona: Anagrama.

MARTín ARIAS, Luis. "Tauromaquia o cómo plantarle cara al horror". Trama y fondo: revista de cultura 12 (2002): 31-44. 
MARTín DE LA GUARDiA, Ricardo (2011). "La movida madrileña en el contexto sociocultural de los años ochenta". Azcona, J.M.; RE, M. y AzPiAzu, M.D (eds.). Sociedad del bienestar, vanguardias artísticas, terrorismo y contracultura. Madrid: Dykinson: 159-173.

METZ, Christian ([1991] 1998). "Filme(s) en el filme". Fime(s) en el film: el intexto filmico. Valencia: Episteme: 1-17.

NaVAjas, Gonzalo (1996). Más allá de la postmodernidad: estética de la nueva novela y cine españoles. Barcelona: EUB.

Oliva, César y TORRes MonReAL, Francisco ([1990] 2003). Historia básica del arte escénico. Madrid: Cátedra,.

PAVIS, Patrice ([1996] 2001). El análisis de los espectáculos: teatro, mimo, danza, cine. Barcelona: Paidós.

PÉrez BowIE, José Antonio. "El cine en, desde y sobre el cine: metaficción, reflexividad e intertextualidad en la pantalla". Anthropos: huellas del conocimiento 208 (2005): 122-137.

PÉrez BowIE, José Antonio. "La teatralidad en la pantalla. Un ensayo de tipología". Signa 19 (2010): 35-62.

PoE, Karen. "The Bolero in the Cinema of Pedro Almodóvar". Music, Sound, and the Moving Image, 4 (2) (2010): 177-195.

RODRíGUEZ, Jesús (2004). Almodóvar y el melodrama de Hollywood: historia de una pasión. Valladolid: Maxtor.

SÁnCHez Noriega, José Luis (2017). Universo Almodóvar: estética de la pasión de un cineasta postmoderno. Madrid: Alianza.

SEARLE, John (1965). ¿Qué es un acto de habla?. Valencia: Revista Teorema.

SONTAG, Susan ([1964] 1996). "Notas sobre lo camp". SonTAG, Susan (ed.). Contra la interpretación. Madrid: Alfaguara: 335-376.

STRAuss, Frédéric (2001). Conversaciones con Pedro Almodóvar. Madrid: Akal.

TóiBín, Colm ([2001] 2002). Love in a Dark Times: Gay Lives from Wilde To Almodóvar: Picador.

TORRE-ESPINOSA, Mario de la. "Nuevos paradigmas críticos para abordar la teatralidad en el cine de Pedro Almodóvar”. Fotocinema. Revista cientifica de cine y fotografía 14 (2017): 111-132.

TORRE-ESPINOSA, Mario de la. "Modelos de intermedialidad en la adaptación cinematográfica del teatro homosexual en el cine de Pedro Almodóvar". Cuadernos de Música, Artes Visuales y Artes Escénicas 1 (2018a): 117-133.

Torre-Espinosa, Mario de la. "Adaptaciones teatrales en el cine de Pedro Almodóvar: Cocteau, Williams y Lorca”. Revista de Comunicación 2 (2018b): 101-124.

UBERSFELD, Anne (2002). Diccionario de términos claves del análisis teatral. Buenos Aires: Galerna.

URIOS-ApARISI, Eduardo (2010). Puro teatro: metáfora y espacio en el cine de Pedro Almodóvar. Valladolid: Ediciones Libertarias. 
Vernon, Kathleen M. (2009). "Queer Sound: Musical Otherness in Three Films by Pedro Almodóvar". EPPS, Bradley y KAKOUDAKI, Despina (eds.). All about Almodóvar: A Passion for Cinema. Minneapolis: University of Minnesota: 51-70.

VILLEGAS, Juan. "De la teatralidad como estrategia multidisciplinaria". Gestos: Teoría y Práctica del Teatro Hispánico 21 (1996): 7-15.

FILMOGRAFíA

Almodóvar, Pedro (1975). Homenaje. España: s.d.

Almodóvar, Pedro (1980). Pepi, Luci, Bom y otras chicas del montón. España: Fígaro Films.

Almodóvar, Pedro (1982). Laberinto de pasiones. España: Alphaville S.A.

Almodóvar, Pedro (1983). Entre tinieblas. España: Tesauro S.A.

Almodóvar, Pedro (1984). ¿Qué he hecho yo para merecer esto? España: Kaktus Producciones Cinematográficas, Tesauro S.A.

Almodóvar, Pedro (1986). Matador. España: Compañía Iberoamericana de TV, en colaboración con Televisión Española.

Almodóvar, Pedro (1987). La ley del deseo. España: El Deseo, Laurenfilm.

Almodóvar, Pedro (1988). Mujeres al borde de un ataque de nervios. España: El Deseo, Laurenfilm.

Almodóvar, Pedro (1989). ¡Átame! España: El Deseo.

Almodóvar, Pedro (1993). Kika. España: El Deseo, CiBy 2000.

Almodóvar, Pedro (1995). La flor de mi secreto. España: El Deseo, CiBy 2000.

Almodóvar, Pedro (1997). Carne trémula. España: El Deseo, CiBy 2000, France 3 Cinéma.

Almodóvar, Pedro (1999). Todo sobre mi madre. España: El Deseo, Renn Productions, France 2 Cinéma, Vía Digital.

Almodóvar, Pedro (2001). Hable con ella. España: El Deseo, Antena 3 Televisión, Good Machine, Vía Digital.

Almodóvar, Pedro (2004). La mala educación. España: El Deseo, Canal + España, Televisión Española.

Almodóvar, Pedro (2009). Los abrazos rotos. España: El Deseo, Canal + España, Televisión Española.

Almodóvar, Pedro (2011). La piel que habito. España: El Deseo, Blue Haze Entertainment, FilmNation Entertainment, Televisión Española.

Almodóvar, Pedro (2013). Los amantes pasajeros. España: El Deseo.

FELLINI, Federico (1972). Roma. Italia: Ultra Film, Les Productions Artistes Associés.

KLEISER, Randal (1978). Grease. Estados Unidos: Paramount Pictures.

MANKIEWICZ, Joseph L. (1950). Eva al desnudo. Estados Unidos: Twentieth Century Fox. 
Mario de la Torre-Espinosa. Intertextos parateatrales en el cine de Pedro Almodóvar...

RAY, Nicholas (1954). Johnny Guitar. Estados Unidos: Republic Pictures.

SIRK, Douglas (1959). Imitación a la vida. Estados Unidos: Universal International Pictures. 